\title{
The Impact of European Union Emissions Trading Scheme (EU ETS) National Allocation Plans (NAP) on Carbon Markets
}

\author{
Andrew Lepone*, Rizwan T. Rahman, Jin-Young Yang \\ Finance Discipline, University of Sydney Business School, Sydney, Australia. \\ Email: andrew.lepone@sydney.edu.au \\ Received January $14^{\text {th }}, 2011$; revised February $11^{\text {th }}, 2011$; accepted March $9^{\text {th }}, 2011$.
}

\begin{abstract}
This paper empirically examines the extent to which participants in the carbon market perceive EU ETS NAP and Verifications announcements to possess informational value. The study directs its attention to carbon returns and volatility movements around official EU ETS PHASE II announcements. Following Mansanet-Bataller and Pardo (2007), we adapt an event study methodology which caters for the peculiarities of our data, using a Regression and Truncated Mean Model approach. Further, we source the earliest date a certain announcement is publicly released from both official and news sources, and examine both Phase I \& II front futures and sole Phase II prices. We find that Phase II announcements have an influence on both Phase I \& II front futures and sole Phase II futures carbon returns. In addition, we find that the announcements have no significant impact on volatility. Together, the findings suggest a systematic leakage of information across all types of announcements, consistent with Mansanet-Bataller \& Pardo (2007).
\end{abstract}

Keywords: Emissions Trading, Carbon Futures, Information Asymmetry

\section{Introduction}

The main rationale for an emissions trading scheme (ETS) is to achieve cost-effective and economic reductions in green house gas emissions. Additionally, it provides a market efficient price for emission units that can be utilized by companies for future investment or business planning purposes. Launched in 2005, the EU ETS now operates in 30 countries (the $27 \mathrm{EU}$ Member States plus Iceland, Liechtenstein and Norway) ${ }^{1}$. It covers $\mathrm{CO}_{2}$ emissions from installations such as power stations, combustion plants, oil refineries and iron and steel works, as well as factories making cement, glass, lime, bricks, ceramics, pulp, paper and board. The first two phases have established the free trading of emission allowances across the EU, put in place the necessary infrastructure and developed a dynamic carbon market. Therefore it is imperative to review the market integrity of the EU ETS as it is central to the pricing and the cost-effective, eco-

\footnotetext{
${ }^{*}$ This research was funded by the Sydney Futures Exchange under Corporations Regulation 7.5.88(2). This paper was improved by the comments of participants of the EFMA 2010 annual meetings.

${ }^{1}$ Emissions Trading System: Policy, European Commission Climate Action, 15 Nov 2010,

http://ec.europa.eu/clima/policies/ets/index en.htm
}

nomic abatement of emissions.

The market for European Union Allowances (EU ETS carbon credits) is characteristically unique in several ways, which introduces a high degree of information asymmetry and uncertainty within the system. First, the asset itself is a product of legislation, where individual governments under the supervision of the European Commission, are responsible for setting emissions caps and allocating EUAs to firms. ${ }^{2}$ Therefore the National Allocation Plans that we examine essentially set the supply of EUAs, and the Verifications report the demand during the preceding period and the remaining supply. Further, because supply and demand in carbon markets operates within constraints set by the ruling government, it creates a level of political risk not present in other markets. Second, a select group of government employees and firm level auditors are apt to information regarding caps and yearly net positions in advance of the market, thereby increasing the likelihood of information leakage and insider trading.

The two major sources of information asymmetry and

\footnotetext{
${ }^{2}$ A European Union Allowance (EUA) gives the holder the right to emit one tonne of carbon dioxide. Each futures contract represents 1,000 EUAs.
} 
uncertainty are derived from the process of setting future emissions caps based on projected figures and past emissions (the supply constraint), and the yearly verification of emission through audits. A National Allocation Plan (NAP), which determines both the total quantity of $\mathrm{CO}_{2}$ allowances available in the Member State and the allocation made to each installation covered by the Scheme, has to be submitted 18 months before the start of a Phase; the European Commission has 3 months to decide upon approval or rejection. Prior to the National allocation plan being delivered to the European Commission, the Member States must each publish a draft for public consultation. It is compulsory that the European Commission approves the NAP of each country. If it is not the case, the NAP will be modified until the European Commission approves it. The procedure makes it difficult to know in advance the exact date of publication of new information. ${ }^{3}$ Figure 1 depicts a timeline of the major announcements between June 2006 and December 2007, prior to Phase II.

Currently, the EU ETS covers more than $11,500^{4}$ installations across Europe, that are obliged to hold an emission permit for their operations, as well as to surrender EUAs corresponding to the installation's $\mathrm{CO}_{2}$ emissions after every year of operations. Each EUA is equal to one tonne of $\mathrm{CO}_{2}$ and can be freely traded between the installations covered by the ETS. The installations are required to surrender emission allowances corresponding to their emissions in the previous year before
30 April. For every tonne of emissions that is not covered by an allowance, a company will have to pay a penalty of $€ 40$ in the first phase and $€ 100$ thereafter. Additionally, around 15 May, the Members States must submit a report of the verified emission to the European Commission including all the companies in the country covered by the European Directive.

Inconsistencies in emissions data from the different reporting agencies also creates a level of information asymmetry and uncertainty among market analysts and diminishes their ability to make accurate assessments of the market. ${ }^{5}$ Emissions data published by the European Environment Agency and the EU transaction log differ substantially. They are collected according to different procedures and sector definitions and sometimes by different government bodies. In addition, the allocation and reporting process for the national allocation plans in Phase I and Phase II lacked transparency and hence led to further uncertainty.

Mansanet-Bataller and Pardo (2007) study the effect of Phase I and Phase II information releases on Phase I prices during the period October 2004 through May 2007. They document that returns are significantly higher on days when the European Commission released additional information and approved Phase I National Allocation Plans. Their results also reveal significantly higher returns after the 2005 verifications and significantly lower returns following 2006 emissions announcements. The study suggests that differences in the EU ETS being short

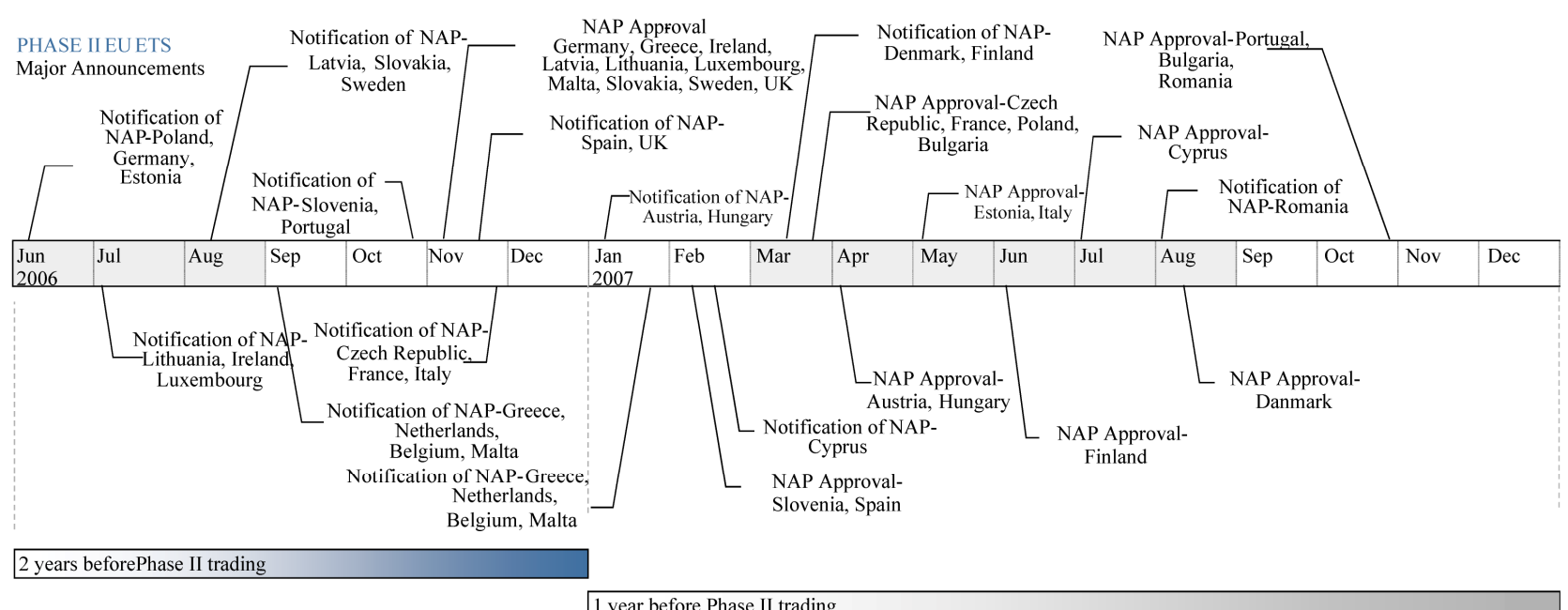

Figure 1. Phase II National Allocation Plan Announcements. This Figure shows major Phase II NAP announcements between 2006 and 2008. Two years before the compliance period, NAPs have to be submitted before 30 June to the European Commission. They have to be approved before 31 December of the same year. The Figure highlights that very few nations abided by the set schedule. In late 2006, the European Commission started infringement proceedings against Austria, Czech Republic, Denmark, Hungary, Italy and Spain, for failure to submit their proposed National Allocation Plans on time.

\footnotetext{
${ }^{3}$ Mansanet-Bataller and Pardo (2007).

${ }^{4}$ Mansanet-Bataller, Tornero, and Mico (2006).

${ }^{5}$ Joost L.M. Kanen, CARBON TRADING AND PRICES, Market inefficiencies: regulatory effects (Chapter 4).
} 
or long during the trading period affected the opposite returns to the verifications data. These results provide evidence that information regarding Phase I NAPs and verifications have a material effect on Phase I carbon prices.

Further, they also examine returns and volatility surrounding the announcement days. The study documents significant returns preceding Phase I National Allocation Plan notification, Phase I NAP additional information, Phase II National Allocation Plan notification, and 2005 verifications announcements. In concert with their finding that volatility is not significantly different following announcements, their study reveals a systematic leakage of information preceding EU ETS announcements.

Following Mansanet-Bataller and Pardo (2007), Miclăuş, Lupu, Dumitrescu, and Bobircă (2008) also examine the effect of EU ETS Phase I \& II National Allocation Plans and Verifications announcements on both spot and futures prices by testing the $\operatorname{AR}(1)-\operatorname{GARCH}(1,1)$ model. The AR-GARCH model in their case presents the markets' expectations, and is used to provide forecast returns in the period around the event. Their methodology analyses both the daily differences in the realised and expected returns as well as the cumulated differences for the period around the event. Consistent with Mansanet-Bataller and Pardo (2007), trends in the cumulated abnormal returns in their study preceding the event suggest that the information about the event is known by some part of the market in advance. They also find that verifications announcements have a greater effect on market dynamics than NAP announcements.

Similarly, Rotfuß, Conrad, and Rittler (2009) investigate price formation around Phase II EU ETS National Allocation Plan Approvals by the European Commission. They develop a model of expectation formation where agents anticipate the EC's decision on Phase II NAPs to account for unexpected information. The paper explicitly employs market expectations and high-frequency data. For each member state, they model the conditional market expectation with respect to the EC's decision on the total number of EUAs in the second NAP. They then regress the surprise element, the difference between the expected and the approved number of EUAs in the second NAP of the member state, on EUA price differences in ten-minute intervals following the announcement. They find that EUA prices react immediately after the publication of the EC's decision on second NAPs. In particular, unexpected cuts lead to price increases and unexpected over-allocation to price decreases. However, they report that the adjustment is not instantaneous, but takes up to six hours after the decision announcement and conclude that the EU ETS is not fully informationally efficient regarding the determination of the size of the overall cap.

Likewise, Chevailler, Ieplo, and Mercier (2008) examine the impact of the 2006 emissions verification announcement on changes in investors' risk aversion on the European Carbon Market using options and futures market data. They test the hypothesis that strong reversals in investors' anticipations occur during the 2006 compliance event, and in addition, that the level of volatility decreases after the diffusion of information by the EC which tends to dissipate previously misleading trading information on this new market. The study empirically recovers risk aversion adjustments on the period 2006 2007 by first estimating the risk-neutral distribution from option prices, and then the actual distribution from futures on the European Climate Exchange. Their study uncovers a shift in the level of risk aversion on the EU ETS following the publication of the 2006 verified emissions data by the EC on April 30, 2007. Further, they observe lower levels of volatility for contracts of maturity December 2008 and December 2009 during the time period after the 2006 compliance event. This latter result suggests that Phase I verification information has a strong market effect.

This study analyzes the impact of Phase II National Allocation Plans announcements on carbon returns during the period February 2006 through December 2008, during which time more than 170 announcements were released. Following Mansanet-Bataller \& Pardo (2007), two event study approaches are used. The first consists of estimating the abnormal returns as coefficients of the dummy variables that correspond to event days in a regression (see Lusk and Schroeder (2002) and Simpson and Ramchander (2004), among others). The second approach is the Constant Mean Return model that measures the abnormal returns from a benchmark period (see Mann and Dowen (1997) and Tse and Hackard (2006), among others). In this study, we follow these two approaches when applying statistical event study methodology using daily carbon futures returns. However, in line with Mansanet-Bataller and Pardo (2007), the unscheduled, sporadic and numerous nature of the announcements affecting a sole price series requires the need to minimize large surprises during the prediction period when applying the Constant Mean Return model. Therefore, the Truncated Mean model is used which is a modification of the Constant Mean Return model in which the abnormal returns in the estimation period are obtained using a truncated mean.

This study differs to that of Mansanet-Bataller and Pardo (2007) in that we focus mainly on EU ETS Phase II announcements (National Allocation Plans) and Phase I verifications on both the front futures (which include both Phase I \& II prices) and the sole Phase II futures 
prices (December 2008 expiry). The study of Phase II prices and announcements is of greater importance because under the EU ETS, it is the first Kyoto Protocol compliant phase of emissions trading. The EU Phase I emissions trading scheme was initiated as a trial phase to prepare for Phase II in which real abatement was to occur. Subsequently, Phase I EUAs were found to be over allocated. Phase II allocations are more restrictive and are likely to lead to a real reduction and abatement in emissions. As reported on April 1, 2009 by the European Commission after the release of 2008 verified emissions data, the second phase ETS was short in 2008 despite the economic downturn. ${ }^{6}$

Further, since mid-2006, the majority of EU ETS trading occurs in the Phase II December 2008 expiry carbon contract. ${ }^{7}$ Therefore the study of Phase II announcements and its impact on both the front futures and Phase II futures returns is likely to yield more robust conclusions regarding the impact of carbon announcements on carbon returns and volatility. This will provide further insights into the operation of the EU ETS into the future, and may highlight regulatory factors which can be improved upon.

An advancement of this study is that we source the earliest date on which an official announcement becomes public by searching through both official and carbon specific news databases. This is an attempt to address a limitation in the Mansanet-Bataller and Pardo (2007) study which does not account for information that becomes public before the official announcement date. Information leakage occurred most notably in Phase I when several member states released their 2005 emissions data ahead of the European Commission's official release date. $^{8}$

The remainder of the paper is organized as follows. The next section describes the data, in particular the carbon futures price series and announcements used in the study. This is followed by an analysis of the impact of the different types of announcements on both returns and volatility in the next two sections. Finally, the last section summarizes the findings and concludes the paper.

\section{Data}

Trading of emission allowance futures contracts is primarily performed through the European Climate Exchange (ECX) in the Netherlands. Since the ECX does not allow spot EUA trading, it uses Powernext spot

\footnotetext{
${ }^{6}$ The World Bank, May 2009, State and Trends of the Carbon Market 2009.

${ }^{7}$ Frino, Kruk, and Lepone (2010) report that the European Climate Exchange Carbon Financial Instrument (ECX CFI) futures represent approximately 80 per cent of exchange traded volume.

${ }^{8}$ Frino, Kruk, and Lepone, 2008, The effects of EUA supply disruptions on market quality in the European carbon market, Australian Securities Exchange Market Insights, Edition 26.
}

prices as a reference for the futures contracts. From 1 February, 2006 to the end of the sample (31 December, 2008), we use the European Climate Exchange (ECX) nearest Carbon Futures Instrument (CFI) contract for the front futures analysis and the ECX CFI with December 2008 expiry for sole Phase II price analysis.

Table 1 summarises the price and announcement data used in previous studies. Although no-arbitrage arguments stipulate that there should not be significant price differences for EUA futures prices with the same maturity among the different exchanges, the ECX futures price emerges as the predominantly used price data in previous academic literature. This is because the ECX accounts for approximately $87 \%$ of the total exchange-based futures contract transactions in Europe and has the greatest volume among all carbon markets. ${ }^{9,10}$ Consistent with prior studies, we use the ECX futures prices to analyse the impact of NAP related announcements on carbon prices as it is the most representative series of EUA prices. The Carbon Index EEX and ECX Futures Price plot in Panel C, Figure III of Mansanet-Bataller and Pardo (2007) appears volatile in nature as a result of the time period under investigation and the futures contracts examined. After a price 'collapse' in April 2006 due to the publication of the 2005 verified emissions data by the EC, the December 2007 futures price asymptotically decreased towards zero because of the impossibility to transfer allowances to the next period. Figure 2 shows our sample features a more stable price series relative to that of Mansanet-Bataller and Pardo (2007). This allows our study to isolate the impact of EU ETS announcements on carbon prices more effectively.

We source the ECX futures contracts data from the Reuters DataScope Tick History (RDTH) Database provided by SIRCA, which includes every bid and ask price submitted each day (together with accurate time stamps). The underlying asset of the futures contract is 1,000 spot EUAs, with the most liquid contracts being those with annual (December) maturities. We use all futures contracts that expire in December of each year between 2006 and 2008. The data correspond to the daily average midpoint of intraday quotes calculated from every quote update within a day.

Finally, given that carbon prices are not stationary, they are converted into stationary returns by taking first logarithm differences. That is, we use continuously compounded returns constructed as $r_{c, t}=\ln \left(P_{c, t} / P_{c, t-1}\right)$, where $P_{c, t}$ is the carbon price at time $t$. The financial economics literature provides evidence that most asset prices are non-stationary. That is, asset prices feature a unit root, which can cause numerous problems in statistical infe-

\footnotetext{
${ }^{9}$ Frino et al., 2010.

${ }^{10}$ Mansanet-Bataller \& Pardo (2007).
} 
Table 1. Summary of Prior Literature.

\begin{tabular}{|c|c|c|c|c|c|}
\hline \multirow{2}{*}{ Exchange } & \multirow{2}{*}{ Instrument } & \multirow{2}{*}{ Expiry } & \multirow{2}{*}{ Announcements Data } & \multicolumn{2}{|c|}{ Time Period } \\
\hline & & & & Start Date & End Date \\
\hline European Energy Exchange (EEX) & Forward & & Dho LNA De \& Vorifiotion & 25-Oct-2004 & 30-Nov-2005 \\
\hline European Climate Exchange (ECX) & Futures & Nearest & 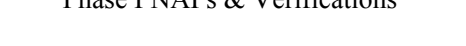 & 1-Dec-2005 & 18-May-2007 \\
\hline European Climate Exchange (ECX) & Futures & 2007 Expiries & Phase I \&II NAPs, Phase I Verifications & 22-Apr-2005 & 17-Dec-2007 \\
\hline European Climate Exchange (ECX) & Futures & Dec 08 & Phase II NAPs & 29-Nov-2006 & 26-Oct-2007 \\
\hline European Climate Exchange (ECX) & Options & Dec 08, Dec 09 & Dh & 1-Oct-2006 & 23-Nov-2007 \\
\hline European Climate Exchange (ECX) & Futures & Dec 08, Dec 10 & Pnase 1,2000 vermications & 1-Oct-2006 & 23-Nov-2007 \\
\hline
\end{tabular}

This table summarises the price and announcement data used in previous literature. In addition it also shows the time period and instruments examined. The Exchange column is the exchange on which the instrument of interest is traded. The Instrument column highlights the financial instrument price series examined while the Expiry column illustrates the contract expiry date. Announcement Data summarises the types of announcements analysed and the Time Period specifies the sample time period under review.

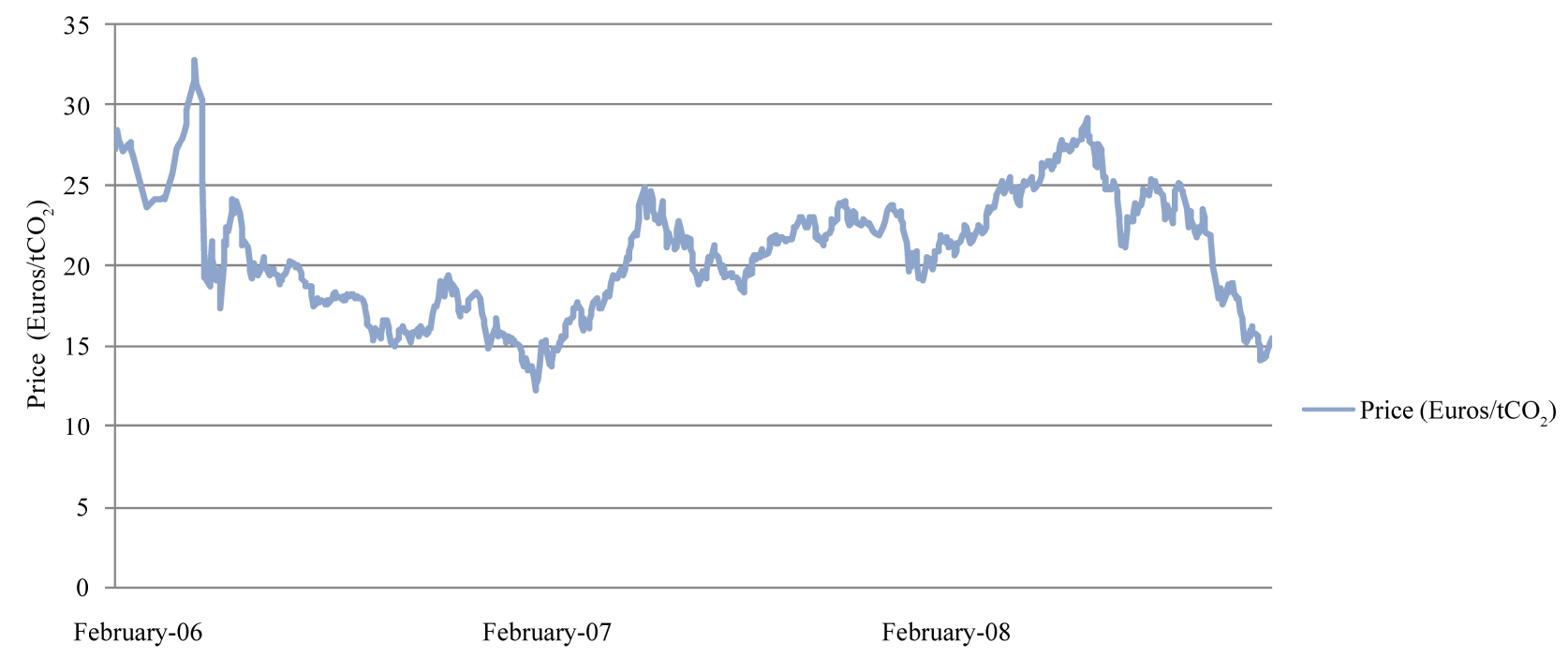

Month/Year

Figure 2. ECX Futures Prices over Sample Period. Figure 2 shows the ECX CFI futures price progression $\left(\mathrm{Euros}^{\mathrm{t}} \mathrm{tCO} \mathrm{O}_{2}\right)$ between February 2006 and December 2008 (our sample period).

rence unless an appropriate adjustment is made. The most commonly used method is to use the returns or logarithm of asset prices since these variables measure 'changes'. The literature also shows that most asset price changes are indeed stationary. Nevertheless, this study examines the presence of a unit root in the carbon price series using the Dickey-Fuller method to test for stationarity of carbon returns and prices during our sample period. The null hypothesis for the Dickey-Fuller test is that the variable of interest has a unit root. Panel A in Table 2 shows that the $p$-values for carbon prices for both contracts (Phase I/II front futures and Phase II (December 2008 futures)) are greater than 0.01 , indicating the presence of a unit root at the $1 \%$ level. In contrast, the p-values for carbon returns are less than 0.0001, which implies that carbon returns are stationary. Additionally, we calculate various statistics of carbon returns in Panel
B of Table 2. Although the Shapiro-Wilk test indicates that carbon returns are not normally distributed, its impact on our statistical inference is limited since: (1) our sample size is large and (2) the test statistics used in this study have properties that ensure asymptotic normality.

Mansanet-Bataller and Pardo (2007) and Chevallier, Ielpo, and Mercier (2008) both study the impact of strictly Phase I announcements. Although, Miclăuş, Lupu, Dumitrescu, and Bobircă (2008) and Rotfuß, Conrad, and Rittler (2009) also analyse Phase II announcements, our examination of abnormal returns and volatility on strictly Phase II futures differentiate our paper from these previous studies. Additionally, our study extends to the end of 2008, once Phase II was already in progress.

The announcement data is gathered from a combination of the European Commission official website, the Community Independent Transaction Log (CITL) web- 
Table 2. Dickey fuller test and statistics of carbon returns.

\begin{tabular}{|c|c|c|}
\hline \multicolumn{3}{|l|}{ Phase I \& II Front Futures } \\
\hline & ADF Statistic (Tau) & $\operatorname{Pr}<\mathrm{Tau}$ \\
\hline Carbon Prices & -2.63 & 0.0871 \\
\hline Carbon Returns & -22.71 & $<0.0001$ \\
\hline \multicolumn{3}{|l|}{ Phase II (Dec, 2008) Futures } \\
\hline & ADF Statistic (Tau) & $\operatorname{Pr}<$ Tau \\
\hline Carbon Prices & -3 & 0.036 \\
\hline Carbon Returns & -17.13 & $<0.0001$ \\
\hline
\end{tabular}

Panel B:

Descriptive Statistics of Carbon Returns

Phase I \& II Front Futures

\begin{tabular}{cc}
\hline & rc \\
\hline Mean & -0.000775 \\
Median & -0.002370 \\
Standard Deviation & 0.293817 \\
Skewness & 6.450795 \\
Kurtosis & 161.5743 \\
Shapiro-Wilk & 0.227434 \\
\hline
\end{tabular}

Phase II (Dec, 2008) Futures

\begin{tabular}{cc}
\hline & rc \\
\hline Mean & -0.000823 \\
Median & -0.000819 \\
Standard Deviation & 0.027997 \\
Skewness & -1.050538 \\
Kurtosis & 8.864452 \\
Shapiro-Wilk & 0.917092 \\
\hline
\end{tabular}

Panel A of this table shows the results of the Dickey-Fuller test for the carbon prices and returns. The critical values for the rejection of the null hypothesis of the existence of a unit root are $-3.4336,-2.8621$ and -2.5671 for $1 \%, 5 \%$, and $10 \%$ significance levels respectively (MacKinnon, 1991). In Panel B the descriptive statistics for carbon returns are shown.

site, and the Point Carbon news archives. From the three sources we are able to determine the earliest date that each announcement is made public. This is a clear improvement on announcement data from the previous literature summarized in Table 1, and an attempt to account for the numerous NAP and verifications information leakages prior to official release dates throughout Phase I and II. There are in total 179 separate announcements on Phase II NAPs and 17 announcements on Phase I verifications.

The various types of announcements are divided into two categories: news strictly related to National Allocation Plans (NAPs) and news related to the Verification of Emissions (VER). In the first group we have 11 subcategories of events: the First Draft of the NAP, Second Draft of the NAP, Initial Notification of the NAP to the European Commission, Second Notification of the NAP to the European Commission, Notification of Additional NAP Information related to the NAP to the European
Commission, NAP Approval by the European Commission, NAP Conditional Approval, NAP Amendment, NAP Amendment Additional Information, NAP Amendment Approval, and Other announcements that relate to the EU ETS such as administrative changes. In the second group, the Verification of Emissions, there are 3 subcategories: verified emissions for the year 2005, verified emissions for the year 2006, and verified emissions for the year 2007. All dates on which more than one different type of announcement occurred are eliminated from the sample for robustness. ${ }^{11}$

\section{Influence of Announcements on Carbon Returns}

If security prices reflect all currently available information, then price changes must reflect new information. Therefore, it is possible to measure the importance of an

\footnotetext{
${ }^{11}$ An analysis which includes all the announcements does not produce results that are qualitatively different. These are available upon request from the authors.
} 
event of interest by examining price changes during the period in which the event occurs. We apply event study methodology to the return series constructed to examine carbon return behavior around NAP and Verification related events. Following Mansanet-Bataller and Pardo (2007), we use two approaches; a regression method, and the Constant Mean Adjusted Return model. This study examines issues similar to those in Mansanet-Bataller and Pardo (2007) using a different sample period. Hence, to directly compare our results (for a more recent period) to those of Mansanet-Bataller and Pardo (2007), the same method is utilised. In addition, this is a standard event study method in the finance literature.

\subsection{Regression Method}

The regression approach involves modelling daily abnormal returns as coefficients of dummy variables for the event period and the returns before and after. The dummy variables are used to parameterize the effects of each particular event. An advantage of this approach is that it takes into account distributional aspects such as volatility clustering, leptokurtosis or the presence of ARCH effects. Following the methodology of MansanetBataller and Pardo (2007), we regress the carbon returns on non-event related explanatory variables and dummy variables representing each of the events considered. Each event variable is equal to one on the announcement day, zero otherwise.

The non-event related variables include the energy commodities variables which are used as explanatory variables of carbon prices. Following Mansanet-Bataller and Pardo (2007), we select the most representative prices of oil and natural gas in Europe. To account for the series of energy variables that better fits the front futures contract of carbon, we also construct the front contract for the energy variables. That is, we select the contract for the energy variables with the closest maturity to the maturity of the carbon contract considered. All series data are obtained from the Reuters Database. The futures contract on WTI Crude Oil is quoted in USD per barrel, the futures contract on Natural Gas is quoted in GBP per therm. Both values are converted into Euros using the daily exchange rate data available from the European Central Bank. ${ }^{12}$ As with carbon prices, energy prices also present a unit root, and are thus converted into stationary returns by taking first logarithm differences.

The dummy variables are analysed in two ways. In the first model, we consider the effect of one dummy variable for each type of event described (NAPs and Verifications). In the second model, we separate the two variables into 14 dummy regressors (explained in the Release of information in the EU ETS section) and re-estimate

\footnotetext{
${ }^{12}$ See http://www.ecb.int.
}

the regressions. For each type of event, the dummy variables are constructed with ones on the days of announcements of its type, and zero otherwise. The regressions are estimated for both the front futures prices and the sole Phase II prices (December 2008 expiry). All regressions are estimated by applying the Newey-West covariance matrix estimator that is consistent with the presence of heteroskedasticity and autocorrelation. The results of the regressions are presented in Tables 2 and 3.

Examining the estimated regressions for the Phase I \& II front futures in Table 3, only in the regression with the dummy variables considered separately are any event coefficients statistically different from zero (see Model 2 in Panel A). The significant variables include WTI Crude Oil returns, Notification of Additional NAP Information, NAP Conditional Approval, and NAP Amendment Approval. These findings suggest that news related to Phase II of the EU ETS affects the front futures contracts which mainly consist of prices from Phase I of the scheme. In addition, all the significant announcements have negative coefficients. This may imply that the EUA market deduced that Phase I EUAs were over allocated by observing the restrictive nature of the NAPs for Phase II. These results are in contrast with that of Mansanet-Bataller and Pardo (2007) who find that Phase II announcements had no significant impact on front futures prices during the period October 2004 through May 2007. A possible explanation is that NAP announcements related to the conditional approval of NAPs and amendments are significant, and these announcements usually arise later in the NAP setting process and are not captured in the sample period examined by Mansanet-Bataller and Pardo (2007).

Additionally, the coefficients associated with verifications of emissions for 2006 are marginally significant at the $10 \%$ level, and are negative. This is explained by the fact that verified emissions were long in 2006. However, the results differ from that of Mansanet-Bataller and Pardo (2007) who find that 2005 verifications also have a significant negative impact on the front futures. On further inspection, it is revealed that the initial primary 2005 verifications announcements were eliminated from the sample because of other confounding announcements on the same days. Those that remain were late verifications data from individual smaller countries.

Assessment of the Phase I and II regression results in Table 3 reveal that the coefficients of determination $\left(\mathrm{R}^{2}\right)$ are extremely low, and fail to explain more than $1.2 \%$ of the variation in carbon returns. Regressions estimated on Phase II (December 2008) returns in Table 4, however, yield superior coefficients of determination at $9.7 \%$ and 10.3\%, respectively. Panel A of Table 4 reveals that both Natural Gas returns and WTI Crude Oil returns are highly significant at the $1 \%$ level, with both having a 
Table 3. Regression model results.

\begin{tabular}{|c|c|c|c|c|}
\hline \multirow[b]{2}{*}{ Variable } & \multicolumn{2}{|c|}{ Model 1} & \multicolumn{2}{|c|}{ Model 2} \\
\hline & Coefficient & t-statistic & Coefficient & t-statistic \\
\hline$\alpha$ & -0.0108 & -1.4001 & 0.0034 & 0.3627 \\
\hline rg,t (Natural Gas returns) & -0.2559 & -1.0226 & -0.2593 & -0.9969 \\
\hline rc,t (WTI Crude returns) & 0.7062 & 2.4669 & 0.8024 & 2.4806 \\
\hline ALL NAPs & 0.0629 & 1.2747 & & \\
\hline ALL Verifications & 0.0083 & 0.2235 & & \\
\hline First Draft of the NAP & & & -0.0027 & -0.1990 \\
\hline Second Draft of the NAP & & & 0.0054 & 0.5369 \\
\hline Initial Notification of the NAP & & & -0.0015 & -0.1237 \\
\hline Second Notification of the NAP & & & 0.0548 & 1.2014 \\
\hline Notification of Additional NAP Information & & & -0.0300 & -2.1984 \\
\hline NAP Approval & & & -0.0018 & -0.0270 \\
\hline NAP Conditional Approval & & & -0.0510 & -2.4132 \\
\hline NAP Amendment & & & 0.0076 & 0.5672 \\
\hline NAP Amendment Additional Information & & & -0.0484 & -1.0303 \\
\hline NAP Amendment Approval & & & -0.2091 & -2.2038 \\
\hline Verification 2005 & & & 0.0050 & 0.0611 \\
\hline Verification 2006 & & & -0.1054 & -1.9440 \\
\hline Verification 2007 & & & -0.0034 & -0.2407 \\
\hline Other & & & -0.1356 & -1.8906 \\
\hline
\end{tabular}

\begin{tabular}{|c|c|c|}
\hline & Model 1 & Model 2 \\
\hline $\mathrm{R}^{2}$ squared & 0.011658 & 0.008686 \\
\hline $\mathrm{R}^{2}$ - Adjusted & 0.006337 & -0.013012 \\
\hline Akaike criterion & 0.330704 & 0.365793 \\
\hline Schwarz criterion & 0.361569 & 0.470734 \\
\hline
\end{tabular}

Panel A presents the estimates of Model (1) and Model (2). In Model (1) the repression of CO2 returns has been calculated on energy variables and dummy variables considered grouped. In Model (2) the regression of CO2 returns has been calculated on energy variables and dummy variables considered separately. Panel B reports the R2, the Adjusted R2, the Akaike Information Criteria (AIC) and the Schwarz Criteria (SC).

positive effect on carbon returns. Panel B reveals similar results for the energy variables. A possible reason that Gas and Oil returns are not significant in explaining carbon returns in Phase I and II front futures, but significant in explaining carbon returns variation in Phase II prices, is that the trial phase EUAs were over-allocated. For a fuel switching price to arise, which would make energy commodities viable explanatory variables of carbon returns, there would have to be a lower supply than de- mand for EUAs. This provides further support for our motivation in examining Phase II prices.

Although the $R^{2}$ in the regressions are very low, it is only of importance when the predictive power of explanatory variables is of interest. In contrast, the objective of this study is to examine whether the relations between the dependent variable and explanatory variables are significant. In this study, therefore, $R^{2}$ is not a relevant statistic. Furthermore, low $R^{2}$ is are common in 
Table 4. Regression Model Results.

\begin{tabular}{|c|c|c|c|c|}
\hline \multirow[b]{2}{*}{ Variable } & \multicolumn{2}{|c|}{ Model 1} & \multicolumn{2}{|c|}{ Model 2} \\
\hline & Coefficient & t-statistic & Coefficient & t-statistic \\
\hline$\alpha$ & -0.0009 & -0.9114 & -0.0006 & -0.6422 \\
\hline rg,t (Natural Gas returns) & 0.0629 & 2.6924 & 0.0627 & 2.8153 \\
\hline rc,t (WTI Crude returns) & 0.3581 & 7.5568 & 0.3571 & 7.7499 \\
\hline ALL NAPs & 0.0006 & 0.2464 & & \\
\hline ALL Verifications & -0.0018 & -0.0765 & & \\
\hline First Draft of the NAP & & & 0.0001 & 0.0216 \\
\hline Second Draft of the NAP & & & -0.0008 & -0.5330 \\
\hline Initial Notification of the NAP & & & -0.0045 & -1.1531 \\
\hline Second Notification of the NAP & & & -0.0014 & -0.2688 \\
\hline Notification of Additional NAP Information & & & -0.0023 & -0.5008 \\
\hline NAP Approval & & & 0.0115 & 0.5126 \\
\hline NAP Conditional Approval & & & 0.0125 & 2.5178 \\
\hline NAP Amendment & & & 0.0091 & 3.6979 \\
\hline NAP Amendment Additional Information & & & -0.0005 & -0.0425 \\
\hline NAP Amendment Approval & & & -0.0136 & -11.4151 \\
\hline Verification 2005 & & & -0.0093 & -0.1837 \\
\hline Verification 2006 & & & -0.0138 & -1.0521 \\
\hline Verification 2007 & & & 0.0056 & 1.0235 \\
\hline Other & & & 0.0000 & 0.0010 \\
\hline
\end{tabular}

Panel B: Goodness of Fit Measures

\begin{tabular}{ccc}
\hline & Model 1 & Model 2 \\
\hline$R^{2}$ squared & 0.0973 & 0.1037 \\
$R^{2}$ - Adjusted & 0.0923 & 0.0838 \\
Akaike criterion & -4.4812 & -4.4558 \\
Schwarz criterion & -4.4500 & -4.3498 \\
\hline
\end{tabular}

Panel A presents the estimates of Model (1) and Model (2). In Model (1) the repression of CO2 returns has been calculated on energy variables and dummy variables considered grouped. In Model (2) the regression of CO2 returns has been calculated on energy variables and dummy variables considered seperately. Panel B reports the R2, the Adjusted R2, the Akaike Information Criteria (AIC) and the Schwarz Criteria (SC).

the empirical finance literature.

Similar to Table 3 , only in the regression with the dummy variables considered separately are any of the announcement dummy variable coefficients statistically different from zero (see Model 2 in Panel A). Both NAP Conditional Approval and NAP Amendment have a significant positive effect on carbon returns, while NAP Amendment Approval has a highly significant (at the 1\% level) negative effect on carbon returns. This may sug- gest that on conditional approval by the European Commission or the request for amendments to the submitted NAP, the market overreacts on average. The subsequent price reduction on news of the amendment approval corresponds to a correction of the market. The results from Table 4, together with the results from Table 3, suggest that news concerning NAPs following their NAP conditional approval or requests for amendments to the NAP by the European Commission are the most significant 
announcements concerning NAPs in Phase II. Examining the sample announcements data, it is quickly apparent that a very small minority of NAPs are approved initially, with most progressing to conditional approvals and requests for amendments. This may explain the findings, and also suggest that in Phase II, the European Commission took a more hardline approach to the approval of NAPs.

Concerning verifications announcements, all the verifications dummy variables are insignificant in explaining any of the variation in Phase II carbon returns. This result is expected as the verifications announcements all relate to Phase I of the EU ETS. In addition, because there is no inter-phase banking of EUAs between Phase I and Phase II, these announcements have no bearing on the Phase II EUA supply or prices.

Overall, the results suggest that carbon returns do react to Phase II announcements, although their impact is greater in Phase II futures. However, because of the uncertain and volatile nature of the market, and inefficiencies in its administration, we require an assessment of the days surrounding an announcement to adequately interpret the results. Furthermore, following McKenzie et al. (2004), the use of all available data could lead to spurious inferences when carbon returns do not present a normal return constant over time. ${ }^{13}$ Additionally, when examining regulatory events on the carbon market, the formal date or the day the information becomes public may not coincide with the date when the new information reaches the market. This is due to the high level of information asymmetry present in the infant stage EU ETS, as discussed earlier. In this case, the use of the regression approach may have little power to reject the null hypothesis of no effect on the carbon price. Based on this, we extend the analysis to include the Truncated Mean model analysis that allows a broader range of days to be analyzed.

\subsection{Truncated Mean Model}

Following Mansanet-Bataller and Pardo (2007), we adopt the truncated mean model approach, which is a truncated version of the Constant Mean Return Model (Brown and Warner, 1985). The abnormal returns are measured as the difference of the returns in $t$ minus a mean return from some benchmark of the estimation period. However, the benchmark return is a truncated average of the estimation period. That is, to calculate the truncated mean return, we exclude the largest and smallest $10 \%$ of returns during the estimation period. As we are examining a sole commodity (carbon prices) which is affected by a large quantity of closed and sporadic announcements, the objective is to minimize the effect of large surprises in the estima-

\footnotetext{
${ }^{13}$ Mansanet-Bataller and Pardo (2007).
}

tion period.

Following Mansanet-Bataller and Pardo (2007), we consider three different scenarios. Panel A of Tables 5 and 6 present results when considering all the announcements released in the sample period. The results are grouped in NAPs and Verifications and Table 5 illustrates the results when examining the Phase I \& II front futures, while Table 6 examines Phase II (December 2008) futures. The second scenario considers only the announcements that do not have another announcement in the three previous days. These results are presented in Panel B of Tables 5 and $\mathbf{6}$. The third scenario is limited to the announcements where no other announcements are released in the six days surrounding it. We consider all three scenarios, each more restrictive than the previous, to assess whether our results are robust given that surrounding announcements could be leading to confounding findings. For example, suppose that two separate national allocation plans are announced on consecutive days, in this case we would not be able to decipher whether abnormal returns or volatility observed in the EUAs prior to the second national allocation plan are because of a leakage of information or whether they were caused by the first national allocation plan announcement. For this reason we have considered the three different scenarios to assess the impact of NAP and verification announcements prior to and following the announcements. These results are presented in Panel C of Tables 5 and 6. Additionally, we undertake the same analysis by substituting the returns series by the residual series of the regression of carbon returns, taking as independent variables the energy variables from the previous section. ${ }^{14}$ The results are presented in Panels A, B and C of Table 5 and $6 .{ }^{15}$

Tables 5 and 6 document that there are many events with statistically significant differences before the announcement date. This occurs when we consider the complete sample (Panel A), and when we consider the other two scenarios (Panels B and C). Additionally, most of the announcement days present statistical significance, suggesting that the new information has an effect on the price series when it becomes public.

For a more in-depth examination of which type of announcement is relevant to the market, we undertake the analysis with the events considered separately. The results for the most restrictive scenario, the one considering only the announcements without any other announcement in the six days surrounding it, are presented in Ta-

\footnotetext{
${ }^{14}$ The specification of the regression is $r_{c, t}=\alpha+\beta_{1} r_{g, t}+\epsilon_{t}$.

${ }^{15} \mathrm{We}$ only present the results with the returns (residuals) standardized with the truncated mean and variance of the estimation period of 10 days. The results of the standardized returns with the truncated mean and variance of the estimation period of 20 and 30 days are qualitatively similar.
} 
Table 5. Truncated mean model results.

\begin{tabular}{|c|c|c|c|c|c|c|c|c|}
\hline \multirow[b]{3}{*}{ Days } & \multicolumn{4}{|c|}{ Returns } & \multicolumn{4}{|c|}{ Residuals } \\
\hline & \multicolumn{2}{|c|}{ ALL NAPs } & \multicolumn{2}{|c|}{ ALL Verifications } & \multicolumn{2}{|c|}{ ALL NAPs } & \multicolumn{2}{|c|}{ ALL Verifications } \\
\hline & ZRt mean & p-value & ZRt mean & p-value & ZRt mean & p-value & ZRt mean & $p$-value \\
\hline-3 & -0.4491 & 0.0000 & -2.3484 & 0.0000 & 0.0275 & 0.7595 & -1.2435 & 0.0000 \\
\hline-2 & 0.4393 & 0.0000 & -1.4315 & 0.0000 & 0.8326 & 0.0000 & -1.5929 & 0.0000 \\
\hline-1 & -0.5132 & 0.0000 & -1.9966 & 0.0000 & -0.5135 & 0.0000 & -2.4266 & 0.0000 \\
\hline 0 & 1.0002 & 0.0000 & -2.5557 & 0.0000 & 0.8751 & 0.0000 & -3.8448 & 0.0000 \\
\hline 1 & -2.6907 & 0.0000 & -4.8835 & 0.0000 & -2.4941 & 0.0000 & -6.9974 & 0.0000 \\
\hline 2 & 0.4405 & 0.0000 & -6.2177 & 0.0000 & 0.6439 & 0.0000 & -8.1976 & 0.0000 \\
\hline 3 & -0.3941 & 0.0000 & -7.6080 & 0.0000 & -1.3347 & 0.0000 & -9.5946 & 0.0000 \\
\hline Number & \multicolumn{2}{|c|}{124} & \multicolumn{2}{|c|}{11} & \multicolumn{2}{|c|}{124} & \multicolumn{2}{|c|}{11} \\
\hline
\end{tabular}

Panel B: Announcements without any other announcement 3 days before.

\begin{tabular}{|c|c|c|c|c|c|c|c|c|}
\hline \multirow[b]{3}{*}{ Days } & \multicolumn{4}{|c|}{ Returns } & \multicolumn{4}{|c|}{ Residuals } \\
\hline & \multicolumn{2}{|c|}{ ALL NAPs } & \multicolumn{2}{|c|}{ ALL Verifications } & \multicolumn{2}{|c|}{ ALL NAPs } & \multicolumn{2}{|c|}{ ALL Verifications } \\
\hline & ZRt mean & $\mathrm{p}$-value & ZRt mean & $p$-value & ZRt mean & $p$-value & ZRt mean & $p$-value \\
\hline-3 & 0.2660 & 0.0967 & -0.8824 & 0.0776 & 2.0553 & 0.0000 & 0.0829 & 0.8683 \\
\hline-2 & -0.0403 & 0.8011 & -2.1632 & 0.0000 & 1.7087 & 0.0000 & -3.0198 & 0.0000 \\
\hline-1 & 0.1327 & 0.4071 & -2.6841 & 0.0000 & 0.0047 & 0.9766 & -2.3527 & 0.0000 \\
\hline 0 & 1.4412 & 0.0000 & 1.8645 & 0.0002 & 2.2176 & 0.0000 & 0.9269 & 0.0638 \\
\hline 1 & -2.3473 & 0.0000 & -17.1697 & 0.0000 & -1.8431 & 0.0000 & -19.5371 & 0.0000 \\
\hline 2 & -3.9144 & 0.0000 & -5.5336 & 0.0000 & -4.9059 & 0.0000 & -6.3544 & 0.0000 \\
\hline 3 & 0.3975 & 0.0130 & 0.4278 & 0.3922 & 1.0239 & 0.0000 & 1.8585 & 0.0002 \\
\hline Number & \multicolumn{2}{|c|}{39} & \multicolumn{2}{|c|}{4} & \multicolumn{2}{|c|}{39} & \multicolumn{2}{|c|}{4} \\
\hline
\end{tabular}

Panel C: Announcements without any other announcement 3 days on either side.

\begin{tabular}{|c|c|c|c|c|c|c|c|c|}
\hline \multirow[b]{3}{*}{ Days } & \multicolumn{4}{|c|}{ Returns } & \multicolumn{4}{|c|}{ Residuals } \\
\hline & \multicolumn{2}{|c|}{ ALL NAPs } & \multicolumn{2}{|c|}{ ALL Verifications } & \multicolumn{2}{|c|}{ ALL NAPs } & \multicolumn{2}{|c|}{ ALL Verifications } \\
\hline & ZRt mean & p-value & ZRt mean & p-value & ZRt mean & p-value & ZRt mean & $p$-value \\
\hline-3 & 0.7089 & 0.0060 & -0.6654 & 0.3467 & 4.8996 & 0.0000 & 0.1418 & 0.8410 \\
\hline-2 & 0.3144 & 0.2234 & -2.2495 & 0.0015 & 3.7597 & 0.0000 & -1.4847 & 0.0358 \\
\hline-1 & -0.4632 & 0.0728 & -3.4980 & 0.0000 & -1.1300 & 0.0000 & -4.1473 & 0.0000 \\
\hline 0 & -1.0108 & 0.0001 & 0.3189 & 0.6520 & -1.0699 & 0.0000 & 0.4499 & 0.5246 \\
\hline 1 & -1.4787 & 0.0000 & -2.3920 & 0.0007 & -1.0767 & 0.0000 & -2.2469 & 0.0015 \\
\hline 2 & 0.0609 & 0.8135 & 0.3247 & 0.6461 & -1.0043 & 0.0001 & 2.0581 & 0.0036 \\
\hline 3 & 2.9829 & 0.0000 & -1.3717 & 0.0524 & 4.0501 & 0.0000 & 0.6343 & 0.3697 \\
\hline Number & \multicolumn{2}{|c|}{15} & \multicolumn{2}{|c|}{2} & \multicolumn{2}{|c|}{15} & \multicolumn{2}{|c|}{2} \\
\hline
\end{tabular}

In this Table we present the results for portfolio excess returns around NAP and verifications announcements on ECX front futures prices. We provide results for the day of the announcement, the 3 previous days and the 3 next days. In Panel A we present the results with the complete sample. In Panel B we consider the announcements days where there has not been an announcement within the 3 previous days. Finally in Panel $\mathrm{C}$ we consider the announcements days where there has not been an announcement within the 6 days round the announcement. The first column in the Table presents the days (" 0 " is the announcement day). The next four columns refer to the standardized returns and the last 4 columns to the standardized residuals of the model 1 in the previous Table regression. The ZRt mean column shows the mean of the portfolio of the standardized returns (residuals) for each of the event groups (NAPs and Verification), and the $p$-value column shows the $p$-value of the test. Number refers to the number of times an announcement of each kind event has been produced. 
Table 6. Truncated mean model results.

\begin{tabular}{|c|c|c|c|c|c|c|c|c|}
\hline \multicolumn{9}{|c|}{ Panel A: All announcements considered. } \\
\hline & \multicolumn{4}{|c|}{ Returns } & \multicolumn{4}{|c|}{ Residuals } \\
\hline & \multicolumn{2}{|c|}{ ALL NAPs } & \multicolumn{2}{|c|}{ ALL Verifications } & \multicolumn{2}{|c|}{ ALL NAPs } & \multicolumn{2}{|c|}{ ALL Verifications } \\
\hline Days & ZRt mean & $p$-value & ZRt mean & p-value & ZRt mean & p-value & ZRt mean & p-value \\
\hline-3 & -0.1838 & 0.0407 & -1.1863 & 0.0001 & 0.0683 & 0.4467 & -1.4209 & 0.0000 \\
\hline-2 & -0.5076 & 0.0000 & -1.5164 & 0.0000 & -0.3617 & 0.0001 & -1.4948 & 0.0000 \\
\hline-1 & -0.0308 & 0.7320 & -1.7113 & 0.0000 & 0.1778 & 0.0478 & -2.1793 & 0.0000 \\
\hline 0 & -0.5196 & 0.0000 & -1.8274 & 0.0000 & -0.3923 & 0.0000 & -1.1827 & 0.0001 \\
\hline 1 & 0.0162 & 0.8571 & -3.3307 & 0.0000 & -0.1842 & 0.0403 & -2.5033 & 0.0000 \\
\hline 2 & 0.3954 & 0.0000 & -3.4139 & 0.0000 & 0.4183 & 0.0000 & -2.1346 & 0.0000 \\
\hline 3 & -0.2579 & 0.0041 & -4.0402 & 0.0000 & -0.3260 & 0.0003 & -2.6905 & 0.0000 \\
\hline Number & 124 & & 11 & & 124 & & 11 & \\
\hline
\end{tabular}

Panel B: Announcements without any other announcement 3 days before.

\begin{tabular}{|c|c|c|c|c|c|c|c|c|}
\hline \multirow[b]{3}{*}{ Days } & \multicolumn{4}{|c|}{ Returns } & \multicolumn{4}{|c|}{ Residuals } \\
\hline & \multicolumn{2}{|c|}{ ALL NAPs } & \multicolumn{2}{|c|}{ ALL Verifications } & \multicolumn{2}{|c|}{ ALL NAPs } & \multicolumn{2}{|c|}{ ALL Verifications } \\
\hline & ZRt mean & p-value & ZRt mean & $p$-value & ZRt mean & $p$-value & ZRt mean & $p$-value \\
\hline-3 & 0.6277 & 0.0001 & -0.2550 & 0.6101 & 0.7736 & 0.0000 & 0.3380 & 0.4991 \\
\hline-2 & -1.2986 & 0.0000 & -2.6091 & 0.0000 & -1.3230 & 0.0000 & -2.9444 & 0.0000 \\
\hline-1 & 0.7475 & 0.0000 & -1.6009 & 0.0014 & 0.8514 & 0.0000 & -1.8199 & 0.0003 \\
\hline 0 & -0.6489 & 0.0001 & 1.0215 & 0.0411 & -0.5685 & 0.0004 & 0.7575 & 0.1297 \\
\hline 1 & 1.1793 & 0.0000 & -6.7492 & 0.0000 & 0.1853 & 0.2472 & -7.0955 & 0.0000 \\
\hline 2 & 1.4828 & 0.0000 & -0.0168 & 0.9732 & 1.2651 & 0.0000 & 0.5334 & 0.2860 \\
\hline 3 & 0.1567 & 0.3279 & 0.5628 & 0.2603 & 0.1103 & 0.4908 & 1.2869 & 0.0101 \\
\hline Number & \multicolumn{2}{|c|}{39} & \multicolumn{2}{|c|}{4} & \multicolumn{2}{|c|}{39} & \multicolumn{2}{|c|}{4} \\
\hline
\end{tabular}

\begin{tabular}{|c|c|c|c|c|c|c|c|c|}
\hline \multirow[b]{3}{*}{ Days } & \multicolumn{4}{|c|}{ Returns } & \multicolumn{4}{|c|}{ Residuals } \\
\hline & \multicolumn{2}{|c|}{ ALL NAPs } & \multicolumn{2}{|c|}{ ALL Verifications } & \multicolumn{2}{|c|}{ ALL NAPs } & \multicolumn{2}{|c|}{ ALL Verifications } \\
\hline & ZRt mean & $p$-value & ZRt mean & p-value & ZRt mean & p-value & ZRt mean & p-value \\
\hline-3 & 0.3820 & 0.1390 & -0.6654 & 0.3467 & 0.2439 & 0.3449 & 0.1657 & 0.8148 \\
\hline-2 & -2.9883 & 0.0000 & -2.2495 & 0.0015 & -2.8924 & 0.0000 & -2.3902 & 0.0007 \\
\hline-1 & 0.5349 & 0.0383 & -3.4980 & 0.0000 & 0.5376 & 0.0373 & -4.5007 & 0.0000 \\
\hline 0 & -2.0054 & 0.0000 & 0.3189 & 0.6520 & -1.4588 & 0.0000 & 0.8007 & 0.2575 \\
\hline 1 & 3.7518 & 0.0000 & -2.3920 & 0.0007 & 1.5065 & 0.0000 & -2.5011 & 0.0004 \\
\hline 2 & 2.4106 & 0.0000 & 0.3247 & 0.6461 & 1.7142 & 0.0000 & 1.8891 & 0.0075 \\
\hline 3 & 1.5976 & 0.0000 & -1.3717 & 0.0524 & 0.6414 & 0.0130 & -0.2258 & 0.7495 \\
\hline Number & \multicolumn{2}{|c|}{15} & \multicolumn{2}{|c|}{2} & \multicolumn{2}{|c|}{15} & \multicolumn{2}{|c|}{2} \\
\hline
\end{tabular}

In this Table we present the results for portfolio excess returns around NAP and verifications announcements on ECX December 2008 expiry futures prices. We provide results for the day of the announcement, the 3 previous days and the 3 next days. In Panel A we present the results with the complete sample. In Panel B we consider the announcements days where there has not been an announcement within the 3 previous days. Finally in Panel $\mathrm{C}$ we consider the announcements days where there has not been an announcement within the 6 days round the announcement. The first column in the Table presents the days (" 0 " is the announcement day). The next four columns refer to the standardized returns and the last 4 columns to the standardized residuals of the model 1 in the previous Table regression. The ZRt mean column shows the mean of the portfolio of the standardized returns (residuals) for each of the event groups (NAPs and Verification), and the $p$-value column shows the $p$-value of the test. Number refers to the number of times an announcement of each kind event has been produced. 
bles 7 and 8. Examining Panel A of both tables, it is apparent that within the NAP announcements category, only on the days of the Initial NAP Notification are there significant positive returns across both the Phase I \& II front futures and the sole Phase II futures. In contrast, the remaining types of announcements in the NAP category, such as Additional NAP info, NAP Approval, NAP Conditional Approval, NAP Amendment Additional Info, and Amendment Approval all exhibit a significant negative reaction. For Phase II futures, it may reflect that the market tends to price in a restrictive cap when member states initially notify the EC of their NAP. Therefore, on subsequent amendments and conditional approvals, the market reduces its perceived expectation of a very restrictive cap and hence the negative reactions. In addition, although the Phase II NAPs are more restrictive and will result in an average cut of nearly $7 \%$ below the 2005 emission levels, the inclusion of offsets undermines this claim. This may be another reason for the negative reactions to the majority of Phase II NAP announcements.

Reviewing the reactions on the days surrounding Verifications announcements (2005 and 2007), we observe that they fail to cause a significant reaction on the day of the announcement. ${ }^{16}$ However, there are significant price movements leading up to the announcement day. This confounding discovery may suggest that there is considerable leakage of verifications data before the information becomes public, and that the information is already impounded into prices. These findings lend further credence to the allegations of a high degree of information asymmetry and possible insider trading concerning EU ETS official announcements. The leakage of information is further pronounced when considering the most restrictive scenario in which there are no other announcements in the 6 days surrounding the announcement of interest. In many cases, the significant price reaction leading up to an announcement is also in the same direction. This again suggests the existence of information leakage.

Panel B of Tables $\mathbf{7}$ and $\mathbf{8}$ present the results when the residual series are considered, and confirm the finding that the market reacts before (or on) the day of the official announcement. Several other announcements such as Initial NAP Notification, Additional NAP Info and NAP Amendment Additional Info also lead to significant reactions beyond $t=0$ in Phase I and II front futures, while Additional NAP Info, NAP Amendment Additional Info, and NAP Amendment Approval all cause significant reactions beyond $t=0$ in the sole Phase II futures. This may suggest that there is uncertainty following information releases in the EUA market, and that it requires sev-

\footnotetext{
${ }^{16}$ Verifications for 2006 are not in the analysis because they were eliminated from the sample as they had other announcements in the 6 days surrounding it.
}

eral days to resolve the uncertainty and accurately price in the information.

\section{Influence of Announcements on Carbon Volatility}

This section reviews the impact of Phase II NAPs and Phase I Verifications announcements on carbon return volatility. This allows an examination of whether there is a systematic leakage of information. As the announcements are mainly unscheduled and sporadic, it is expected that upon becoming public, there will be a higher degree of volatility as the news is priced in. However, if there is no change in volatility, it may suggest a systematic leakage of information before it becomes public.

To test the difference in volatility before and after the event, we undertake two tests - the Brown-Forsythe test and the sign test. Consistent with the previous section, we use both the return series and the residual series of the regression.

\subsection{Brown and Forsythe Test}

The Brown-Forsythe test allows testing for seasonality in the unconditional variance. Following Mansanet-Bataller and Pardo (2007), applying this test to the peculiarities of the sample is coherent with the idea of minimising the effects of large surprises in the estimation period. Specifically, we consider a prediction period of 10 days and have separated it into two sub-periods, both of 5 days. The first sub-period consists of the 5 days preceding the announcement and the second sub-period includes the announcement day and the following 4 days. Therefore, the division of the prediction period is the announcement day.

We present the results of the Brown-Forsythe test applied to the announcement days without any other announcement on the 6 days around it in Panels A and B of Tables 9 and 10. This sample is chosen for two reasons. First, following this criteria we are consistent with the more restrictive analysis of the impact of the announcements on carbon returns presented in the previous section. Second, if we apply the test only to announcement days without any other announcement during the 10-day prediction period, the sample will be drastically reduced. Additionally, the Brown-Forsythe test uses the mean absolute deviation from the median, and thus the possible extreme values provoked by an announcement in the prediction period will not distort the results.

Focusing on Panel A of Tables 9 and 10, the results for the Brown-Forsythe test for both the return series and the residual series are similar. If we consider the variables grouped in NAPs and Verifications (Panel A), in both cases the null hypothesis is never rejected. Furthermore, NAP announcements lead to a higher variance 
Table 7. Truncated mean model results: Events separated.

Panel A: Results with the Returns series

\begin{tabular}{|c|c|c|c|c|c|c|c|c|c|c|c|c|c|c|c|c|}
\hline & First Dra & aft NAP & $\begin{array}{l}\text { Initial } \\
\text { Notific }\end{array}$ & $\begin{array}{l}\text { NAP } \\
\text { cation }\end{array}$ & $\begin{array}{l}\text { Addit } \\
\text { NAP }\end{array}$ & $\begin{array}{l}\text { tional } \\
\text { Info }\end{array}$ & NAP Al & pproval & $\begin{array}{r}\mathrm{N} A \\
\text { Condi } \\
\text { Appr }\end{array}$ & $\begin{array}{l}\text { JAP } \\
\text { ditional } \\
\text { proval }\end{array}$ & $\begin{array}{r}\mathrm{N} \\
\text { Ammer } \\
\text { Additio }\end{array}$ & $\begin{array}{l}\text { AP } \\
\text { ndment } \\
\text { nal Info }\end{array}$ & $\begin{array}{r}\text { Amme } \\
\text { App }\end{array}$ & $\begin{array}{l}\text { endment } \\
\text { roval }\end{array}$ & $\begin{array}{l}\text { Verification } \\
\quad 2005\end{array}$ & $\begin{array}{l}\text { Verification } \\
2007\end{array}$ \\
\hline Days & $\begin{array}{c}\text { ZRt } \\
\text { mean }\end{array}$ & p-value & $\begin{array}{c}\text { ZRt } \\
\text { mean }\end{array}$ & p-value & $\begin{array}{c}\text { ZRt } \\
\text { mean }\end{array}$ & p-value & $\begin{array}{c}\text { ZRt } \\
\text { mean }\end{array}$ & p-value & $\begin{array}{c}\text { ZRt } \\
\text { mean }\end{array}$ & p-value & $\begin{array}{c}\text { ZRt } \\
\text { mean }\end{array}$ & p-value & $\begin{array}{c}\text { ZRt } \\
\text { mean }\end{array}$ & p-value & ${ }_{\text {mean }}^{\mathrm{ZRt}} p$-value & ${ }_{\text {mean }}^{\mathrm{ZRt}} p$-value \\
\hline-3 & -1.3099 & 0.0233 & -4.6476 & 0.0000 & 5.4844 & 0.0000 & -0.4178 & 0.5546 & -9.9273 & 30.0000 & 0.1494 & 0.8813 & 0.2911 & 0.7709 & -3.99050 .0001 & 2.65980 .0078 \\
\hline-2 & -5.5094 & 0.0000 & -7.6383 & 0.0000 & 6.3348 & 0.0000 & 0.3130 & 0.6580 & 2.6993 & 0.0069 & -5.2550 & 0.0000 & -1.592 & 00.1114 & -1.82140 .0685 & -2.67760 .0074 \\
\hline-1 & -1.2728 & 0.0275 & -1.1904 & 0.2339 & -0.9661 & 0.0308 & 1.0438 & 0.1399 & 3.1270 & 0.0018 & -6.3464 & 0.0000 & 3.7069 & 0.0002 & -3.26500 .0011 & -3.73100 .0002 \\
\hline 0 & 1.9077 & 0.0010 & 6.3023 & 0.0000 & -1.5619 & 0.0005 & -2.6032 & 0.0002 & -0.4401 & 10.6599 & -12.732 & 10.0000 & -2.990 & 50.0028 & $0.4065 \quad 0.6844$ & 0.23130 .8171 \\
\hline 1 & -0.5729 & 0.3211 & -2.8623 & 0.0042 & -3.7676 & 0.0000 & 0.3130 & 0.6580 & 0.1525 & 0.8788 & -0.3973 & 0.6911 & -2.358 & 30.0184 & -5.00770 .0000 & 0.22370 .8230 \\
\hline 2 & 0.7078 & 0.2202 & -0.1149 & 0.9085 & 0.7910 & 0.0770 & 0.3130 & 0.6580 & 0.2460 & 0.8057 & -10.344 & 90.0000 & 4.8386 & 0.0000 & -3.09290 .0020 & 3.74220 .0002 \\
\hline 3 & 0.0617 & 0.9149 & 0.4521 & 0.6512 & 3.4524 & 0.0000 & 0.3130 & 0.6580 & -0.6645 & 0.5064 & 20.0081 & 0.0000 & 4.2553 & 0.0000 & -2.61360 .0090 & -0.12970 .8968 \\
\hline $\begin{array}{c}\text { Num- } \\
\text { ber }\end{array}$ & & 3 & & 1 & & 5 & & 2 & & 1 & 1 & 1 & & 1 & 1 & 1 \\
\hline
\end{tabular}

Panel B: Results with the Residuals series

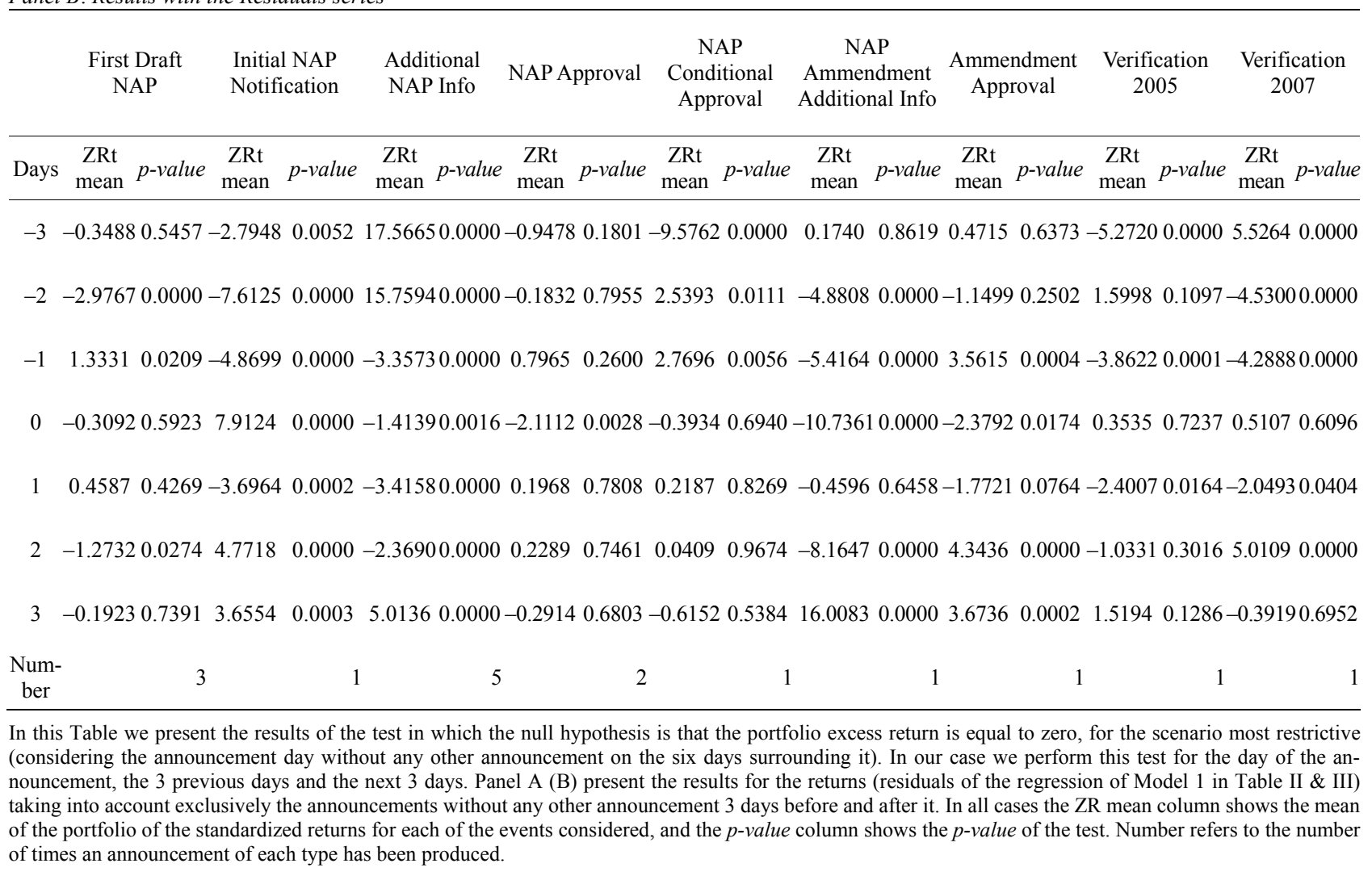


Table 8. Truncated mean model results: Events separated.

Panel A: Results with the Returns series

\begin{tabular}{|c|c|c|c|c|c|c|c|c|c|c|c|c|c|c|c|c|}
\hline \multicolumn{3}{|c|}{ First Draft NAP } & \multicolumn{2}{|c|}{$\begin{array}{l}\text { Initial NAP } \\
\text { Notification }\end{array}$} & \multicolumn{2}{|c|}{$\begin{array}{l}\text { Additional } \\
\text { NAP Info }\end{array}$} & \multicolumn{2}{|c|}{ NAP Approval } & \multicolumn{2}{|c|}{$\begin{array}{l}\text { NAP Condi- } \\
\text { tional Approval }\end{array}$} & \multicolumn{2}{|c|}{$\begin{array}{c}\text { NAP Am- } \\
\text { mendment } \\
\text { Additional Info }\end{array}$} & \multicolumn{2}{|c|}{$\begin{array}{l}\text { Ammendment } \\
\text { Approval }\end{array}$} & $\begin{array}{l}\text { Verification } \\
\quad 2005\end{array}$ & \multirow{2}{*}{$\begin{array}{l}\text { Verification } \\
2007 \\
\begin{array}{c}\text { ZRt } \\
\text { mean }\end{array} \text {-value }\end{array}$} \\
\hline Days & s $\begin{array}{c}\mathrm{ZRt} \\
\text { mean }\end{array}$ & p-value & $\begin{array}{c}\text { ZRt } \\
\text { mean }\end{array}$ & p-value & $\begin{array}{c}\text { ZRt } \\
\text { mean }\end{array}$ & p-value & $\begin{array}{c}\text { ZRt } \\
\text { mean }\end{array}$ & p-value & $\begin{array}{l}\text { ZRt } \\
\text { mean }\end{array}$ & p-value & $\begin{array}{c}\mathrm{ZRt} \\
\text { mean }\end{array}$ & $p$-value & $\begin{array}{c}\text { ZRt } \\
\text { mean }\end{array}$ & p-value & $\underset{\text { mean }}{\mathrm{ZRt}} p$-value & \\
\hline-3 & -3.5919 & 0.0000 & -5.5658 & 0.0000 & 1.4548 & 0.0011 & 7.3746 & 0.0000 & -5.0173 & 30.0000 & 2.4492 & 0.0143 & 4.5832 & 0.0000 & -3.99050 .0001 & 2.65980 .0078 \\
\hline-2 & -19.912 & 30.0000 & -10.1226 & 0.0000 & 1.6944 & 0.0002 & 6.7554 & 0.0000 & 0.8945 & 0.3710 & 2.9014 & 0.0037 & -0.9804 & 40.3269 & -1.82140 .0685 & -2.67760 .0074 \\
\hline-1 & -0.7119 & 0.2176 & 5.1078 & 0.0000 & 0.2491 & 0.5776 & -0.2819 & 0.6902 & 6.2884 & 0.0000 & -3.0389 & 0.0024 & -2.8124 & 40.0049 & -3.26500 .0011 & -3.73100 .0002 \\
\hline 0 & -0.9286 & 60.1078 & 5.6758 & 0.0000 & -2.3993 & 30.0000 & -6.6001 & 0.0000 & -2.7645 & 50.0057 & -4.3156 & 50.0000 & -1.2485 & 50.2119 & $0.4065 \quad 0.6844$ & 0.23130 .8171 \\
\hline 1 & 17.7824 & 40.0000 & 1.7209 & 0.0853 & 0.5567 & 0.2132 & 0.7229 & 0.3066 & 2.8590 & 0.0043 & -3.7886 & 60.0002 & -1.4100 & 0.1585 & -5.00770 .0000 & 0.22370 .8230 \\
\hline 2 & 2.9102 & 0.0000 & -2.0113 & 0.0443 & 3.2430 & 0.0000 & 8.6674 & 0.0000 & 2.4379 & 0.0148 & 1.7191 & 0.0856 & 0.7976 & 0.4251 & -3.09290 .0020 & 3.74220 .0002 \\
\hline 3 & -0.2835 & 50.6234 & 3.5712 & 0.0004 & 2.7995 & 0.0000 & 5.2110 & 0.0000 & 1.9657 & 0.0493 & 2.1178 & 0.0342 & 0.8921 & 0.3723 & -2.61360 .0090 & -0.12970 .8968 \\
\hline $\begin{array}{l}\text { Num- } \\
\text { ber }\end{array}$ & & 3 & & 1 & & 5 & & 2 & 2 & 1 & & 1 & & 1 & 1 & 1 \\
\hline
\end{tabular}

Panel B: Results with the Residuals series

\begin{tabular}{|c|c|c|c|c|c|c|c|c|c|}
\hline & First Draft NAP & $\begin{array}{l}\text { Initial NAP } \\
\text { Notification }\end{array}$ & $\begin{array}{l}\text { Additional } \\
\text { NAP Info }\end{array}$ & NAP Approval & $\begin{array}{c}\text { NAP } \\
\text { Conditional } \\
\text { Approval }\end{array}$ & $\begin{array}{c}\text { NAP } \\
\text { Ammendment } \\
\text { Additional Info }\end{array}$ & $\begin{array}{c}\text { Ammendment } \\
\text { Approval }\end{array}$ & $\begin{array}{l}\text { Verification } \\
\quad 2005\end{array}$ & $\begin{array}{l}\text { Verification } \\
\quad 2007\end{array}$ \\
\hline Days & $\underset{\text { mean }}{\mathrm{ZRt}} p$-value & $\underset{\text { mean }}{\text { ZRt }}$ p-value & $\underset{\text { mean }}{\mathrm{ZRt}} p$-value & $\operatorname{Znt}_{\text {mean }}^{\mathrm{ZRt}} p$-value & $\underset{\text { mean }}{\mathrm{ZRt}} \mathrm{p}$-value & $\underset{\text { mean }}{\text { ZRt }}$-value & $\underset{\text { mean }}{\text { ZRt }}$ p-value & $\underset{\text { mean }}{\mathrm{ZRt}}$-value & $\underset{\text { mean }}{\mathrm{ZRt}} \mathrm{p}$-value \\
\hline
\end{tabular}

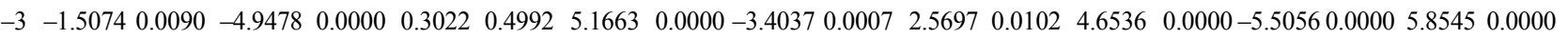

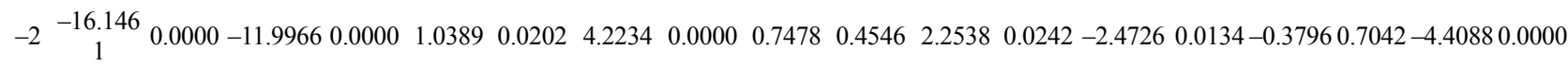

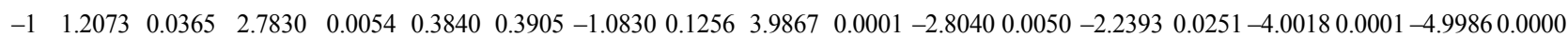

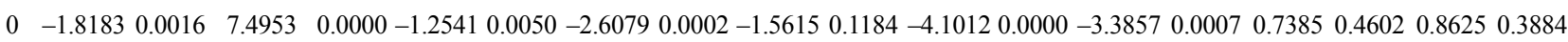

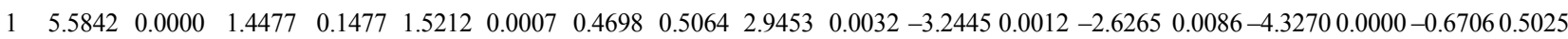

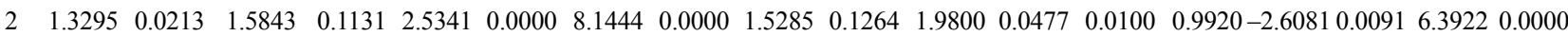

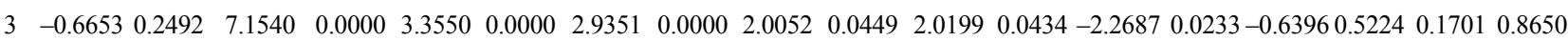

$\begin{array}{ccccccccc}\begin{array}{c}\text { Nu- } \\ \text { mber }\end{array} & 3 & 1 & 5 & 2 & 1 & 1 & 1 & 1\end{array}$

In this Table we present the results of the test in which the null hypothesis is that the portfolio excess return is equal to zero, for the scenario most restrictive (considering the announcement day without any other announcement on the six days surrounding it). In our case we perform this test for the day of the announcement, the 3 previous days and the next 3 days. Panel A (B) present the results for the returns (residuals of the regression of Model 1 in Table II \& III) taking into account exclusively the announcements without any other announcement 3 days before and after it. In all cases the ZR mean column shows the mean of the portfolio of the standardized returns for each of the events considered, and the p-value column shows the p-value of the test. Number refers to the number of times an announcement of each type has been produced. 
Table 9. Equality test results.

Panel A: Brown-Forsythe test for events considered grouped

\begin{tabular}{|c|c|c|c|c|c|}
\hline \multirow[b]{2}{*}{ Null Hypothesis } & \multirow[b]{2}{*}{$\begin{array}{l}\text { Alternative } \\
\text { Hypothesis }\end{array}$} & \multicolumn{2}{|c|}{ Returns } & \multicolumn{2}{|c|}{ Residuals } \\
\hline & & NAPs & VER & NAPs & VER \\
\hline$\sigma_{0}=\sigma_{1}$ & $\sigma_{0} \neq \sigma_{1}$ & $0 \%$ & $0 \%$ & $0 \%$ & $0 \%$ \\
\hline$\sigma_{0}=\sigma_{1}$ & $\sigma_{0}<\sigma_{1}$ & $0 \%$ & $0 \%$ & $0 \%$ & $0 \%$ \\
\hline$\sigma_{0}=\sigma_{1}$ & $\sigma_{0}>\sigma_{1}$ & $0 \%$ & $0 \%$ & $0 \%$ & $0 \%$ \\
\hline \multicolumn{2}{|c|}{ Number of announcements $=$} & 15 & 2 & 15 & 2 \\
\hline
\end{tabular}

\begin{tabular}{|c|c|c|c|c|c|c|c|c|c|c|}
\hline \multicolumn{11}{|c|}{ Panel B: Brown-Forsythe test for events considered separated } \\
\hline \multicolumn{11}{|c|}{ Returns } \\
\hline $\begin{array}{c}\text { Null } \\
\text { Hypothesis }\end{array}$ & $\begin{array}{l}\text { Alternative } \\
\text { Hypothesis }\end{array}$ & $\begin{array}{l}\text { First } \\
\text { Draft }\end{array}$ & $\begin{array}{c}\text { Initial } \\
\text { Notfication }\end{array}$ & $\begin{array}{l}\text { Additional } \\
\text { Info }\end{array}$ & Approval & $\begin{array}{c}\text { Condi- } \\
\text { tional } \\
\text { Approval }\end{array}$ & $\begin{array}{l}\text { Ammendment } \\
\text { Additional Info }\end{array}$ & $\begin{array}{c}\text { Am- } \\
\text { mendment } \\
\text { Approval }\end{array}$ & $\begin{array}{l}\text { VER } \\
2005\end{array}$ & $\begin{array}{l}\text { VER } \\
2007\end{array}$ \\
\hline$\sigma_{0}=\sigma_{1}$ & $\sigma_{0} \neq \sigma_{1}$ & $0 \%$ & $0 \%$ & $0 \%$ & $0 \%$ & $0 \%$ & $0 \%$ & $0 \%$ & $0 \%$ & $0 \%$ \\
\hline$\sigma_{0}=\sigma_{1}$ & $\sigma_{0}<\sigma_{1}$ & $0 \%$ & $0 \%$ & $0 \%$ & $0 \%$ & $0 \%$ & $0 \%$ & $0 \%$ & $0 \%$ & $0 \%$ \\
\hline$\sigma_{0}=\sigma_{1}$ & $\sigma_{0}>\sigma_{1}$ & $0 \%$ & $0 \%$ & $0 \%$ & $0 \%$ & $0 \%$ & $0 \%$ & $0 \%$ & $0 \%$ & $0 \%$ \\
\hline Number of a & ouncements = & 3 & 1 & 5 & 2 & 1 & 1 & 1 & 1 & 1 \\
\hline \multicolumn{11}{|l|}{ Residuals } \\
\hline $\begin{array}{c}\text { Null } \\
\text { Hypothesis }\end{array}$ & $\begin{array}{l}\text { Alternative } \\
\text { Hypothesis }\end{array}$ & $\begin{array}{l}\text { First } \\
\text { Draft }\end{array}$ & $\begin{array}{c}\text { Initial } \\
\text { Notfication }\end{array}$ & $\begin{array}{l}\text { Additional } \\
\text { Info }\end{array}$ & Approval & $\begin{array}{c}\text { Condi- } \\
\text { tional } \\
\text { Approval }\end{array}$ & $\begin{array}{l}\text { Ammendment } \\
\text { Additional Info }\end{array}$ & $\begin{array}{c}\text { Am- } \\
\text { mendment } \\
\text { Approval }\end{array}$ & $\begin{array}{l}\text { VER } \\
2005\end{array}$ & $\begin{array}{l}\text { VER } \\
2007\end{array}$ \\
\hline$\sigma_{0}=\sigma_{1}$ & $\sigma_{0} \neq \sigma_{1}$ & $0 \%$ & $0 \%$ & $0 \%$ & $0 \%$ & $0 \%$ & $0 \%$ & $0 \%$ & $0 \%$ & $0 \%$ \\
\hline$\sigma_{0}=\sigma_{1}$ & $\sigma_{0}<\sigma_{1}$ & $0 \%$ & $0 \%$ & $0 \%$ & $0 \%$ & $0 \%$ & $0 \%$ & $0 \%$ & $0 \%$ & $0 \%$ \\
\hline$\sigma_{0}=\sigma_{1}$ & $\sigma_{0}>\sigma_{1}$ & $0 \%$ & $0 \%$ & $0 \%$ & $0 \%$ & $0 \%$ & $0 \%$ & $0 \%$ & $0 \%$ & $0 \%$ \\
\hline \multicolumn{2}{|c|}{ Number of announcements $=$} & 3 & 1 & 5 & 2 & 1 & 1 & 1 & 1 & 1 \\
\hline
\end{tabular}

\begin{tabular}{|c|c|c|c|c|c|}
\hline \multicolumn{6}{|c|}{ Panel C: Sign test for the events considered grouped } \\
\hline & & \multicolumn{2}{|c|}{ Returns } & \multicolumn{2}{|c|}{ Residuals } \\
\hline Null Hypothesis & Alternative Hypothesis & NAPs & VER & NAPs & VER \\
\hline$\sigma_{0}=\sigma_{1}$ & $\sigma_{0}>\sigma_{1}$ & 0.3036 & 0.2500 & 0.6964 & 0.2500 \\
\hline$\sigma_{0}=\sigma_{1}$ & $\sigma_{0}<\sigma_{1}$ & 0.8491 & 1.0000 & 0.5000 & 1.0000 \\
\hline \multicolumn{2}{|c|}{ Number of announcements $=$} & 15 & 2 & 15 & 2 \\
\hline
\end{tabular}

\begin{tabular}{|c|c|c|c|c|c|c|c|c|c|c|}
\hline \multicolumn{11}{|c|}{ Panel D: Sign test for the events considered separated } \\
\hline \multicolumn{11}{|c|}{ Returns } \\
\hline $\begin{array}{c}\text { Null } \\
\text { Hypothesis }\end{array}$ & $\begin{array}{l}\text { Alternative } \\
\text { Hypothesis }\end{array}$ & $\begin{array}{l}\text { First } \\
\text { Draft }\end{array}$ & $\begin{array}{c}\text { Initial } \\
\text { Notfication }\end{array}$ & $\begin{array}{l}\text { Additional } \\
\text { Info }\end{array}$ & Approval & $\begin{array}{l}\text { Conditional } \\
\text { Approval }\end{array}$ & $\begin{array}{l}\text { Ammendment } \\
\text { Additional Info }\end{array}$ & $\begin{array}{l}\text { Ammendment } \\
\text { Approval }\end{array}$ & $\begin{array}{l}\text { VER } \\
2005\end{array}$ & $\begin{array}{l}\text { VER } \\
2007\end{array}$ \\
\hline$\sigma_{0}=\sigma_{1}$ & $\sigma_{0}>\sigma_{1}$ & 0.5000 & 0.5000 & 0.5000 & 0.7500 & 0.5000 & 1.0000 & 0.5000 & 0.5000 & 0.5000 \\
\hline$\sigma_{0}=\sigma_{1}$ & $\sigma_{0}<\sigma_{1}$ & 0.8750 & 1.0000 & 0.8125 & 0.7500 & 1.0000 & 0.5000 & 1.0000 & 1.0000 & 1.0000 \\
\hline Number of ann & ouncements $=$ & 3 & 1 & 5 & 2 & 1 & 1 & 1 & 1 & 1 \\
\hline \multicolumn{11}{|l|}{ Residuals } \\
\hline $\begin{array}{c}\text { Null } \\
\text { Hypothesis }\end{array}$ & $\begin{array}{l}\text { Alternative } \\
\text { Hypothesis }\end{array}$ & $\begin{array}{l}\text { First } \\
\text { Draft }\end{array}$ & $\begin{array}{c}\text { Initial } \\
\text { Notfication }\end{array}$ & $\begin{array}{l}\text { Additional } \\
\text { Info }\end{array}$ & Approval & $\begin{array}{l}\text { Conditional } \\
\text { Approval }\end{array}$ & $\begin{array}{l}\text { Ammendment } \\
\text { Additional Info }\end{array}$ & $\begin{array}{l}\text { Ammendment } \\
\text { Approval }\end{array}$ & $\begin{array}{l}\text { VER } \\
2005\end{array}$ & $\begin{array}{l}\text { VER } \\
2007\end{array}$ \\
\hline$\sigma_{0}=\sigma_{1}$ & $\sigma_{0}>\sigma_{1}$ & 0.5000 & 1.0000 & 0.8125 & 0.7500 & 0.5000 & 1.0000 & 0.5000 & 0.5000 & 0.5000 \\
\hline$\sigma_{0}=\sigma_{1}$ & $\sigma_{0}<\sigma_{1}$ & 0.8750 & 0.5000 & 0.5000 & 0.7500 & 1.0000 & 0.5000 & 1.0000 & 1.0000 & 1.0000 \\
\hline Number of ann & ouncements $=$ & 3 & 1 & 5 & 2 & 1 & 1 & 1 & 1 & 1 \\
\hline
\end{tabular}

This Table presents the results of two equality tests. Panel A (B) shows the results of the Brown-Forsythe test for the carbon returns and the residuals series considered grouped (separated). Panel C (D) shows the p-value for the standardized returns and residual series sign test for the variables considered grouped (separated). In all cases, the null hypothesis is that the variance during the 5 days preceding the announcement day is equal to the variance in the period made up of the announcement day and the next 4 days. In Panel A and B, the times the null hypothesis is rejected expressed in percentage. The different rows present the results for the possible alternative hypothesis. The last row shows the total of announcements of each type of event. In order to be consistent with the previous analysis, the announcement days considered are those without any announcement on the 6 days around it. For both Panel C and D, the series are standardized with the truncated mean and variance of a period of 10 days. 
Table 10. Equality test results.

\begin{tabular}{cccccc}
\hline \multicolumn{2}{l}{ Panel A: Brown-Forsythe test for events considered grouped } & \multicolumn{2}{c}{ Residuals } \\
\hline \multirow{2}{*}{ Null Hypothesis } & Alternative Hypothesis & NAPs & VER & \multirow{2}{*}{ NAPs } & VER \\
\hline$\sigma_{0}=\sigma_{1}$ & $\sigma_{0} \neq \sigma_{1}$ & $0 \%$ & $0 \%$ & $0 \%$ & $0 \%$ \\
$\sigma_{0}=\sigma_{1}$ & $\sigma_{0}<\sigma_{1}$ & $7 \%$ & $0 \%$ & $7 \%$ & $0 \%$ \\
$\sigma_{0}=\sigma_{1}$ & $\sigma_{0}>\sigma_{1}$ & $0 \%$ & $0 \%$ & $0 \%$ & $0 \%$ \\
\multicolumn{2}{l}{ Number of announcements } & 15 & 2 & 15 & 2 \\
\hline
\end{tabular}

\begin{tabular}{|c|c|c|c|c|c|c|c|c|c|c|}
\hline \multicolumn{11}{|l|}{ Returns } \\
\hline $\begin{array}{c}\text { Null } \\
\text { Hypothesis }\end{array}$ & $\begin{array}{l}\text { Alternative } \\
\text { Hypothesis }\end{array}$ & $\begin{array}{l}\text { First } \\
\text { Draft }\end{array}$ & $\begin{array}{c}\text { Initial } \\
\text { Notfication }\end{array}$ & $\begin{array}{l}\text { Additional } \\
\text { Info }\end{array}$ & Approval & $\begin{array}{c}\text { Conditional } \\
\text { Approval }\end{array}$ & $\begin{array}{l}\text { Ammendment } \\
\text { Additional Info }\end{array}$ & $\begin{array}{l}\text { Ammendment } \\
\text { Approval }\end{array}$ & VER 2005 & VER 2007 \\
\hline$\sigma_{0}=\sigma_{1}$ & $\sigma_{0} \neq \sigma_{1}$ & $0 \%$ & $0 \%$ & $0 \%$ & $0 \%$ & $0 \%$ & $0 \%$ & $0 \%$ & $0 \%$ & $0 \%$ \\
\hline$\sigma_{0}=\sigma_{1}$ & $\sigma_{0}<\sigma_{1}$ & $0 \%$ & $0 \%$ & $20 \%$ & $0 \%$ & $0 \%$ & $0 \%$ & $0 \%$ & $0 \%$ & $0 \%$ \\
\hline$\sigma_{0}=\sigma_{1}$ & $\sigma_{0}>\sigma_{1}$ & $0 \%$ & $0 \%$ & $0 \%$ & $0 \%$ & $0 \%$ & $0 \%$ & $0 \%$ & $0 \%$ & $0 \%$ \\
\hline Number of ann & ouncements = & 3 & 1 & 5 & 2 & 1 & 1 & 1 & 1 & 1 \\
\hline \multicolumn{11}{|l|}{ Residuals } \\
\hline $\begin{array}{c}\text { Null } \\
\text { Hypothesis }\end{array}$ & $\begin{array}{l}\text { Alternative } \\
\text { Hypothesis }\end{array}$ & $\begin{array}{l}\text { First } \\
\text { Draft }\end{array}$ & $\begin{array}{c}\text { Initial } \\
\text { Notfication }\end{array}$ & $\begin{array}{l}\text { Additional } \\
\text { Info }\end{array}$ & Approval & $\begin{array}{c}\text { Conditional } \\
\text { Approval }\end{array}$ & $\begin{array}{l}\text { Ammendment } \\
\text { Additional Info }\end{array}$ & $\begin{array}{c}\text { Ammendment } \\
\text { Approval }\end{array}$ & VER 2005 & VER 2007 \\
\hline$\sigma_{0}=\sigma_{1}$ & $\sigma_{0} \neq \sigma_{1}$ & $0 \%$ & $0 \%$ & $0 \%$ & $0 \%$ & $0 \%$ & $0 \%$ & $0 \%$ & $0 \%$ & $0 \%$ \\
\hline$\sigma_{0}=\sigma_{1}$ & $\sigma_{0}<\sigma_{1}$ & $0 \%$ & $0 \%$ & $20 \%$ & $0 \%$ & $0 \%$ & $0 \%$ & $0 \%$ & $0 \%$ & $0 \%$ \\
\hline$\sigma_{0}=\sigma_{1}$ & $\sigma_{0}>\sigma_{1}$ & $0 \%$ & $0 \%$ & $0 \%$ & $0 \%$ & $0 \%$ & $0 \%$ & $0 \%$ & $0 \%$ & $0 \%$ \\
\hline \multicolumn{2}{|c|}{ Number of announcements $=$} & 3 & 1 & 5 & 2 & 1 & 1 & 1 & 1 & 1 \\
\hline
\end{tabular}

\begin{tabular}{|c|c|c|c|c|c|}
\hline \multicolumn{6}{|c|}{ Panel C: Sign test for the events considered grouped } \\
\hline & & \multicolumn{2}{|c|}{ Returns } & \multicolumn{2}{|c|}{ Residuals } \\
\hline Null Hypothesis & Alternative Hypothesis & NAPs & VER & NAPs & VER \\
\hline$\sigma_{0}=\sigma_{1}$ & $\sigma_{0}>\sigma_{1}$ & 0.5000 & 0.2500 & 0.6964 & 0.2500 \\
\hline$\sigma_{0}=\sigma_{1}$ & $\sigma_{0}<\sigma_{1}$ & 0.6964 & 1.0000 & 0.5000 & 1.0000 \\
\hline \multicolumn{2}{|c|}{ Number of announcements $=$} & 15 & 2 & 15 & 2 \\
\hline
\end{tabular}

Panel D: Sign test for the events considered separated

Returns

\begin{tabular}{|c|c|c|c|c|c|c|c|c|c|c|}
\hline $\begin{array}{c}\text { Null } \\
\text { Hypothesis }\end{array}$ & $\begin{array}{l}\text { Alternative } \\
\text { Hypothesis }\end{array}$ & $\begin{array}{l}\text { First } \\
\text { Draft }\end{array}$ & $\begin{array}{c}\text { Initial } \\
\text { Notfication }\end{array}$ & $\begin{array}{l}\text { Additional } \\
\text { Info }\end{array}$ & Approval & $\begin{array}{c}\text { Conditional } \\
\text { Approval }\end{array}$ & $\begin{array}{l}\text { Ammendment } \\
\text { Additional Info }\end{array}$ & $\begin{array}{c}\text { Ammendment } \\
\text { Approval }\end{array}$ & VER 2005 & VER 2007 \\
\hline$\sigma_{0}=\sigma_{1}$ & $\sigma_{0}>\sigma_{1}$ & 0.5000 & 0.5000 & 0.5000 & 1.0000 & 0.5000 & 1.0000 & 0.5000 & 0.5000 & 0.5000 \\
\hline$\sigma_{0}=\sigma_{1}$ & $\sigma_{0}<\sigma_{1}$ & 0.8750 & 1.0000 & 0.8125 & 0.2500 & 1.0000 & 0.5000 & 1.0000 & 1.0000 & 1.0000 \\
\hline Number of ann & ouncements $=$ & 3 & 1 & 5 & 2 & 1 & 1 & 1 & 1 & 1 \\
\hline \multicolumn{11}{|l|}{ Residuals } \\
\hline $\begin{array}{c}\text { Null } \\
\text { Hypothesis }\end{array}$ & $\begin{array}{l}\text { Alternative } \\
\text { Hypothesis }\end{array}$ & $\begin{array}{l}\text { First } \\
\text { Draft }\end{array}$ & $\begin{array}{c}\text { Initial } \\
\text { Notfication }\end{array}$ & $\begin{array}{l}\text { Additional } \\
\text { Info }\end{array}$ & Approval & $\begin{array}{l}\text { Conditional } \\
\text { Approval }\end{array}$ & $\begin{array}{l}\text { Ammendment } \\
\text { Additional Info }\end{array}$ & $\begin{array}{l}\text { Ammendment } \\
\text { Approval }\end{array}$ & VER 2005 & VER 2007 \\
\hline$\sigma_{0}=\sigma_{1}$ & $\sigma_{0}>\sigma_{1}$ & 0.5000 & 0.5000 & 0.9688 & 0.7500 & 0.5000 & 1.0000 & 0.5000 & 0.5000 & 0.5000 \\
\hline$\sigma_{0}=\sigma_{1}$ & $\sigma_{0}<\sigma_{1}$ & 0.8750 & 1.0000 & 0.1875 & 0.7500 & 1.0000 & 0.5000 & 1.0000 & 1.0000 & 1.0000 \\
\hline \multicolumn{2}{|c|}{ Number of announcements $=$} & 3 & 1 & 5 & 2 & 1 & 1 & 1 & 1 & 1 \\
\hline
\end{tabular}

This Table presents the results of two equality tests. Panel A (B) shows the results of the Brown-Forsythe test for the carbon returns and the residuals series considered grouped (separated). Panel C (D) shows the p-value for the standardized returns and residual series sign test for the variables considered grouped (separated). In all cases, the null hypothesis is that the variance during the 5 days preceding the announcement day is equal to the variance in the period made up of the announcement day and the next 4 days. In Panel A and B, the times the null hypothesis is rejected expressed in percentage. The different rows present the results for the possible alternative hypothesis. The last row shows the total of announcements of each type of event. In order to be consistent with the previous analysis, the announcement days considered are those without any announcement on the 6 days around it. For both Panel C and D, the series are standardized with the truncated mean and variance of a period of 10 days. 
after the announcement only in $7 \%$ of the cases when examining Phase II returns.

Panel B of Tables $\mathbf{9}$ and $\mathbf{1 0}$ present results where the events are considered separately for both Phase I and II front futures. None of the announcements provoke any change in carbon variance, when examining both returns and residuals. For Phase II futures, only Additional NAP information announcements cause an increase in carbon variance following the announcement in $20 \%$ of the cases, both for returns and residuals. Finally, in no case is the null hypothesis rejected when considering the announcements related to verification of emissions.

Overwhelmingly, the results illustrate that the majority of announcements cause no statistical difference in variance following the announcement, which is in concert with the findings of Mansanet-Bataller and Pardo (2007). In the isolated case where the variance before and after the announcement is statistically different, an increase of the variance is detected after the announcement. This latter result is in contrast to Chevailler, Ieplo, and Mercier (2008) who report lower levels of volatility following announcements. Overall, our findings are consistent with the notion that NAP and verification related announcements do not have a significant effect on carbon volatility.

\subsection{Sign Test of Carbon Variance}

Following Mansanet-Bataller and Pardo (2007) and Milonas (1987), we undertake the equality test of the variance of the standardized excess returns to completely assess the equality of the variance before and after announcements. Consistent with the previous analysis, we also apply this test to the residual series. Specifically, we separate the period which comprises of the 5 previous days to the announcement from the period comprised of the day of the announcement and the next 4 consecutive days. We then test the equality of the variances of the standardized returns explained in the Truncated Mean Model section with $l=5$ between the two sub-periods. As in the case of the Brown-Forsythe test, and for the same reasons, we consider the sample period of the announcements without any other announcements during the 6 days surrounding it.

The results of the one-sided tests for the events considered grouped are shown in Panel C of Tables 9 and 10, and the results of the test for the events considered separately are in Panel D. ${ }^{17}$ In both cases, the p-value is presented for the two possible alternative hypotheses. As shown in Panels C and D of Table 9, for all of the events, the carbon returns present the same variances before and after the event unanimously (all p-values are larger than

\footnotetext{
${ }^{17}$ In this case, the returns and residuals are standardized with the truncated mean and variance of a period of 10 days.
}

$\alpha=0.05)$. In the case of the residuals series, it is not possible to reject the null hypothesis and consequently we cannot reject the equality of variances of the residual series before and after the announcement. The results of the tests are the same for all types of events, independent of whether we consider the variables grouped together or separately. These results are consistent with the results obtained with the previous test, and indicate a statistically insignificant effect of Phase II EU ETS NAP announcements on carbon volatility.

\section{Conclusions}

The EU emissions trading scheme highlights various design issues related to the efficiency and equity of such market-based mechanisms. An efficient system would lead to the equalization of marginal abatement costs among participants, yielding a unique market price that acts as a medium-term signal for investors to make cost estimates of delivering different levels of energy efficiency and the size of emissions abatement. During its Pilot Phase, the EU ETS failed to provide appropriate incentives. This investigation sheds light on the effectiveness of central regulatory agencies such as the EC, national governments and reporting authorities in providing a fair and equitable platform for the goal of economically reducing emissions.

This study is based on the notion that commodity markets are information driven mechanisms which determine equilibrium prices. If markets are active, the information is quickly disseminated among market participants who, upon trading, determine a fair price. Prices can also reflect information which is not publicly announced by a governmental agency but yet successfully forecasted by private agents or leaked by insiders as illustrated by our study.

We find that Phase II NAP announcements have an effect on both Phase I and II front futures and the sole Phase II futures contracts. That is, Phase II NAP announcements act as new information for the Phase I EU ETS. Phase I verifications announcements, however, only affect the Phase I and II front futures, which is consistent with the information inherent in Phase I verifications, and the no banking of allowances between phases restriction. We also detect significant returns on days leading up to both NAP and Verifications information becoming public. Further, we find no significant differences in the volatility of carbon returns before and after NAP and Verifications announcements. Consistent with the findings of Mansanet-Bataller and Pardo (2007) regarding Phase I NAP announcements, we find that there are significant abnormal returns up to 3 days prior to several Phase II NAP-related events, and that there is an absence of volatility effects when the information be- 
comes public. Together, these findings suggest a systematic leakage of information across all types of announcements.

An equitable system would involve allocating allowances based on uniform criteria that is mostly perceived as fair and agreed upon by the various stakeholders. In contrast, the first two trading periods consisted of widely different national methods for allocating allowances to installations threatening fair competition in the internal market and creating a level of political risk not present in other markets. Our findings support the proposed changes to Phase III of the scheme by the European Commission announced in January $2008^{18}$, where the allocation of EUAs is centralized to an EU authority (no more national allocation plans). Further, this will lead to a greater harmonization, clarification and refinement of processes and information dissemination within the system. This will in effect directly address the constant leakage of emissions cap data and reduce the high level of information asymmetry and uncertainty previously inherent in the EUA markets. These changes are a constructive improvement for all stakeholders considering the previous request made by the European Federation of Energy Traders (EFET, 2006) to the European Commission for carbon price sensitive information that was "accurate, final and published in such a way as to be available to all market participants at the same time".

\section{REFERENCES}

[1] E. Alberola, J. Chevallier and B. Cheze, "European carbon Prices Fundamentals 2005-2007: The Effects of Energy Markets, Temperatures, and Sectorial Production," Working Paper, University of Paris, Paris, 2007.

[2] S. J. Brown and J. B. Warner, "Using Daily Stock Returns: The Case of Event Studies," Journal of Financial Economics, Vol. 14, No. 1, 1985, pp. 3-31. doi:10.1016/0304-405X(85)90042-X

[3] J. Chevallier, F. Ielpo and L. Mercier, "Risk Aversion and Institutional Information Disclosure on the European Carbon Markets," Working Paper, University of Paris, Paris, 2008.

[4] J. Chevallier, F. Ielpo and L. Mercier, "Risk Aversion and Institutional Information Disclosure on the European Carbon Market: A Case-Study of the 2006 Compliance Event," Energy Policy, Vol. 37, No. 1, 2009, pp. 15-28. doi:10.1016/j.enpol.2008.07.030

[5] F. Convery and L. Redmond, "Market and Price Developments in the European Union Emissions Trading Scheme," Review of Environmental Economics and Policy, Vol. 1, No. 1, 2007, pp. 88-111.

${ }^{18}$ Questions and Answers on the Commission's proposal to revise the EU Emissions Trading System, MEMO/08/35, Brussels, 23 January 2008,

http://europa.eu/rapid/pressReleasesAction.do?reference=MEMO/08/35 $\&$ format $=$ HTML\&aged $=0$ \&language $=E N \&$ guiLanguage $=$ en doi:10.1093/reep/rem010

[6] G. Daskalakis and R. Markellos, “Are Electricity Risk Premia Affected by the Emission Allowance Prices? Evidence from the EEX, Nord Pool and Powernext," Energy Policy, Vol. 37, No. 7, 2009, pp. 2594-2604.

[7] G. Daskalakis D. Psychoyios and R. Markellos, "Modelling $\mathrm{CO}_{2}$ Emission Allowance Prices and Derivatives: Evidence from the European Trading Scheme," Journal of Banking \& Finance, Vol. 33, No. 7, 2009, pp. 1230-1241.

[8] G. Daskalakis and R. Markellos, "Are the European Carbon Markets Efficient?" Review of Futures Markets, Vol. 17, No. 2, 2008, pp. 103-128.

[9] A. Frino, J. Kruk and A. Lepone, "Liquidity and Transaction Costs in the European Carbon Futures Market," Journal of Derivatives and Hedge Funds, Vol. 16, No. 2, 2010, pp. 100-115. doi:10.1057/jdhf.2010.8

[10] J. L. Lusk and T. C Schroeder, "Effects of Meat Recalls on Futures Market Prices," Agricultural and Resource Economics Review, Vol. 31, No. 1, 2002, pp. 47-58.

[11] T. L. Mann and R. J. Dowen, "The Impact of Proprietary-Public Information on Pork Futures," The Journal of Futures Markets, Vol. 17, No. 4, 1997, 417-432. doi:10.1002/(SICI)1096-9934(199706)17:4<417::AID-F UT3>3.0.CO;2-K

[12] M. Mansanet-Bataller, A. Tornero and E. Mico, " $\mathrm{CO}_{2}$ Prices, Energy and Weather," Working Paper, University of Valencia, Valencia, 2006.

[13] M. Mansanet-Bataller, A. Pardo amd E. Valor, " $\mathrm{CO}_{2}$ Prices, Energy and Weather," The Energy Journal, Vol. 28, 2007, pp. 73-92. doi:10.5547/ISSN0195-6574-EJ-Vol28-No3-5

[14] M. Mansanet-Bataller amd A. Pardo, "The Effects of National Allocation Plans on Carbon Markets," Working Paper, University of Valencia, Valencia, 2007.

[15] A. M. McKenzie, M. R. Thomsen and B. L. Dixon, "The Performance of Event Study Approaches Using Daily Commodity Futures Returns," The Journal of Futures Markets, Vol. 24, No. 6, 2004, pp. 533-555. doi:10.1002/fut.10126

[16] P. G. Miclăuş, R. Lupu, S. A. Dumitrescu and A. Bobircă, "Testing the Efficiency of the European Carbon Futures Market Using Event-Study Methodology," International Journal of Energy and Environment, Vol. 2, No. 2, 2008, pp. 121-128.

[17] N. Milonas, "The Effects of USDA Crop Announcements on Commodity Prices," The Journal of Futures Markets, Vol. 7, No. 5, 1987, pp. 571-589. doi:10.1002/fut.3990070509

[18] G. Milunovich and R. Joyeux, "Market Efficiency and Price Discovery in the EU Carbon Futures Market," $A p$ plied Financial Economics, Vol. 20, No. 10, 2010, pp. 32-48.

[19] W. Rotfuß, C. Conrad and D. Rittler, "The European Commission and EUA Prices: A High-Frequency Analysis of the EC's Decisions on Second NAPs," The Centre for European Economic Research, Mannheim, 2009.

[20] J. Sijm, K. Neuhoff and Y. Chen, " $\mathrm{CO}_{2}$ Cost Pass through 
and Windfall Profits in the Power Sector," Climate Policy, Vol. 6, No. 1, 2006, pp. 49-72. doi:10.3763/cpol.2006.0604

[21] M. W. Simpson and S. Ramchander, "An Examination of the Impact of Macroeconomic News on the Spot and Futures Treasuries Markets," The Journal of Futures Markets, Vol. 24, No. 5, 2004, pp. 453-478. doi:10.1002/fut.10132
[22] Y. Tse and J. C. Hackard, "Holy Mad Cow! Facts or (Mis) Perceptions: A Clinical Study," The Journal of Futures Markets, Vol. 26, No. 4, 2006, pp. 315-341. doi:10.1002/fut.20200

[23] R. R. Wilcox, "Fundamentals of Modern Statistical Methods: Substantially Improving Power and Accuracy," Springer-Verlag New York Inc., New York, 2001.

\section{APPENDIX}

\section{Augmented Dickey - Fuller Test Statistics for Energy Variables.}

This Table shows the results of the Augmented Dickey Fuller test for all the energy series taken into account in the regression approach (Natural Gas and WTI Crude Oil) in all cases for both prices and returns. The critical values for the rejection of the null hypothesis of the existence of a unit root in the series are $-3.4336,-2.8621$ and -2.5671 for $1 \%, 5 \%$ and $10 \%$ significance levels (MacKinnon, 1991).

Table 1. Results of the Augmented Dickey - Fuller test.

\begin{tabular}{ccc}
\hline & ADF Statistic (Tau) & $\operatorname{Pr}<$ Tau \\
\hline Natural Gas Prices & -1.05 & 0.7356 \\
Natural Gas Returns & -19.31 & $<0.0001$ \\
WTI Crude Prices & -0.92 & 0.7814 \\
WTI Crude Returns & -17.93 & $<0.0001$ \\
\hline
\end{tabular}

Table 2. ECX CFI Contract Specifications' Regards Andrew.

\begin{tabular}{ll}
\hline Contract & ECX CFI Futures \\
\hline Unit of trading & 1 lot $=1,000 \mathrm{CO}_{2}$ EU Allowances (EUAs) \\
& $1 \mathrm{EUA}=$ entitlement to emit 1 tonne of $\mathrm{CO}_{2}$ or equivalent \\
Minimum trade size & 1 lot \\
Quotation & Euro $(€)$ and Euro cent (c) per metric tonne \\
Tick size & $€ 0.01$ per tonne ( $€ 10$ per lot)* \\
Max. price fluctuation & No limit \\
Contract months & Monthly - September 2006 to March 2008 (Phase I) \\
& Yearly - December expired 2008 to 2012 (Phase II) \\
Expiry day & Last Monday of contract month \\
Trading hours & $07: 00$ - 17:00 UK local time \\
Settlement price & Trade-weighted average during the daily closing period (17:00 - 17:15) with Quoted \\
& Settlement Prices if liquidity is low. \\
Settlement and delivery & $\begin{array}{l}\text { Physically settled. Transfer of EUAs in a national registry three days after last trading } \\
\text { dat (LTD + 3 delivery) } \\
\text { All open contracts marked-to-market daily }\end{array}$ \\
\end{tabular}

